\title{
الجوانب التشريعية للميراث وآثاره الاقتصادية والاجتماعية وشبهاته \\ المعاصرة- دراسة في نصوص الوحيين
}

\section{عبدالرحمن عبدالناصر سيد سلطان}

أستاذ الحديث النبوي وعلومه المساعد بكلية الآداب جامعة المنيا- جمهورية مصر العربية dr.abdalrhman2014@yahoo.com 
الجو انب التشريعية للميراث و آثاره الاقتصهادية والاجتماعية وشبهاته المعاصرةدراسة في نصوص الوحيين

\author{
عبدالرحمن عبدالناصر سيد سلطان

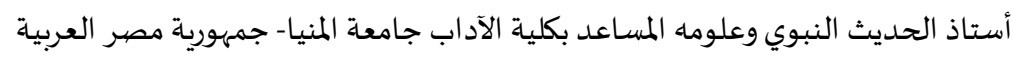 \\ dr.abdalrhman2014@yahoo.com
}

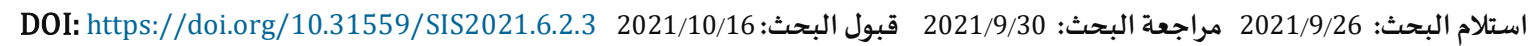

تقتصر الدراسة على مجموعة أطر أساسية توضح معالمه،، وهي: نظام الميراث في الإسلام، وأسساه وغاياته، وآثاره

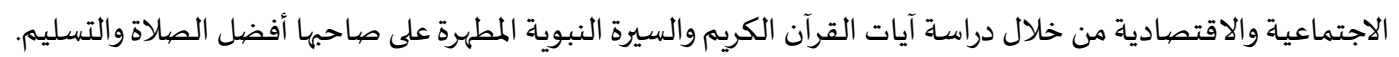
تناولت الدراسة مفهوم الميراث وأركانه وشروطه وأسباباه وموانعه، والجوانب التشريعية الخاصية بميراث المرأة، والأثر

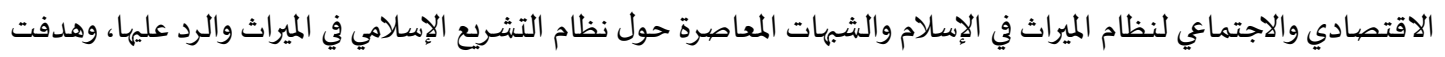

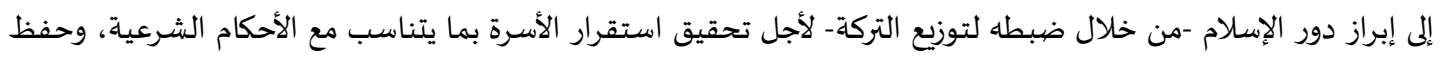
الحقوق لها بمعرفة الضوابط السليمة التي حددنها الشريعة الإسلامية في التعامل مع الورثة، ومن أهم النتائج التي توصلت إليها أن للإعجاز التشريعي في الميراث مقاصد شرعية سامية تتبلور في جلب المصالح ودرء المفاسد، ومن هذه المقاصيد: تحقيق مبدأ

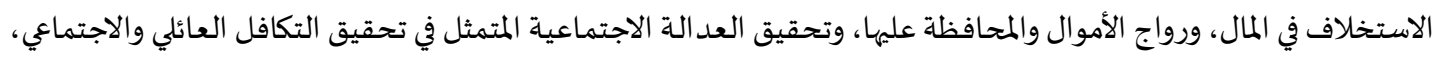
وتوزيع الإرث بين كل من يستحقه من الذكور والإناث والصغار والكبار، وتهفيار. الكلمات المفتاحية: التشريح؛ المرأة؛ الميراث؛ الأثر.

المقدمة:

الحمد الله الذي شرع لعباده من الدين ما يُصلح به دنياهم وأخراهم، وسن لهم من الأحكام والشرائع ما يعيشون باه آمنين مطمئنين، ويَحيَون باه سعداء مشمولين بعدل الحاكمين، واستقامة المحكومين.

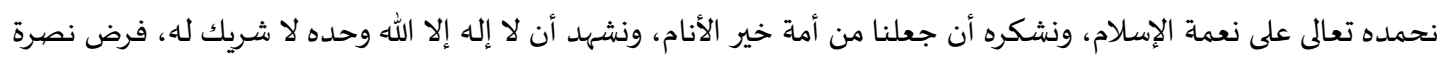
المظلوم، والأخذ على يد الظالم، والنصح لكل مسلم، واجتناب الآثام، وحذر من نقض العقود، ومجاوزة الحدود، ثم وعد وتوعد الحدا

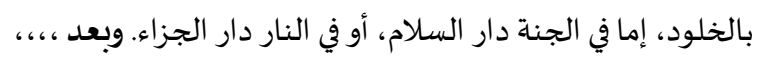
فالشريعة الإسلامية نظام متكامل ينظم سائر شؤون الناس: الشخصياة، والاجتماعية، والاقتصادية، والسياسية، والأمنية،

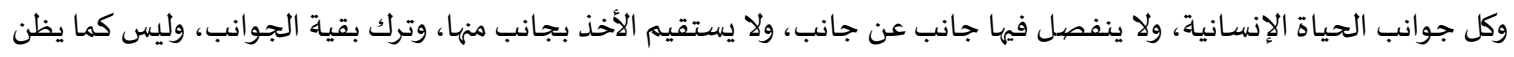

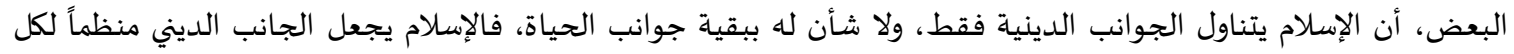

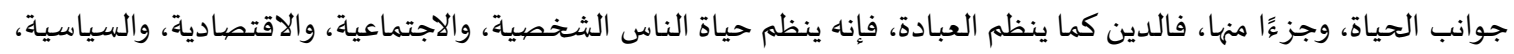


وعلى هذا نجد أنّ الإسلام عندما شرع الميراث جعله يرتبط في تقسيم التركة على العديد من الضوابط المهمة، منها مسؤولية

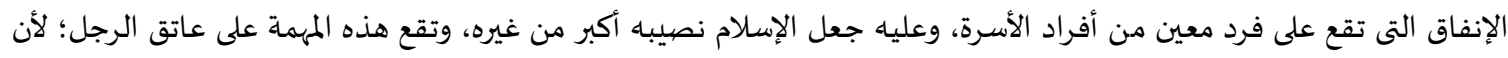

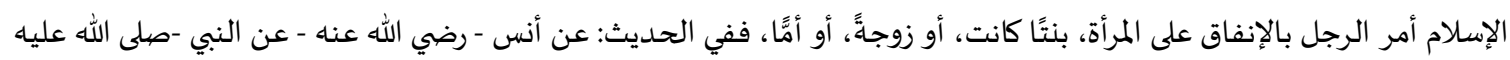

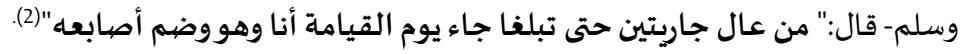

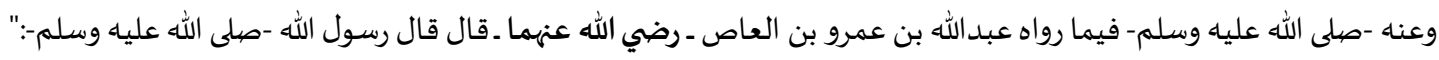

كفى بالمرء إثما أن يضيع من يقوت "(3). وقد عنى القرآن الكريم والسنة النبوية كذلك ببيان التشريع الإسلامي في نظام الميراث، والإعلاء من مكانته، وتحديد ضيوابطه،

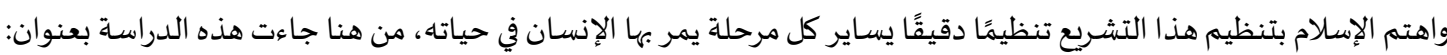

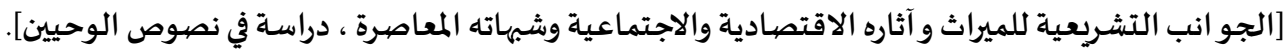

أهمية موضيوع الدراسة والباعث على اختيارها: 1. بيان أهمية موضوع الميراث في الإسلام وآثاره الاجتماعية، والتربوية، وإعلاء مكانة التشريع من خلال ذكر النماذج من سنة النبي

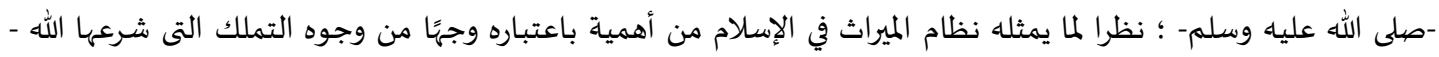
عزوجل - للإنسان من تطبيق أحكام الله وحدوده في المجتمع.

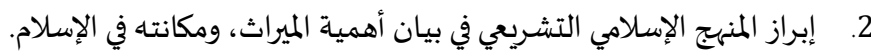
3. البحث عن عوامل وضوابط تطبيق نظام الميراث في الإسلام، فهو ترسيخ لنظرية الحقوق والواجبات التى أقرتها الشريعة الإسالامية. 4. معرفة الادعاءات الكاذبة والمغلوطة التي دارت حول تشريع الميراث في العصر الحديث، ودحضها. أهداف الدراسـة: 1. بيان دور المؤسسات الإسلامية في إبراز الوعي داخل المجتمع بقضية الميراث في ضوء الواقع والتحديات المعاصرة في تربية أفرادها على مبادئ القرآن الكريم، والسنة المطهرة. 2. إبراز دور الإسلام - من خلال ضبطه لتوزيع التركة - لأجل تحقيق استقرار الأسرة بما يتناسب مع الأحكام الشرعية، وحفظ الحقوق لها بمعرفة الضوابط السليمة التى حددتها الشريعة الإسلامية في التعامل مع الورثة. 3. توضيح دور التشريع الإسلامي في ضوء نظرية الحقوق والواجبات في موضوع الميراث، مع إبراز حقوق الأفراد، وإعلاء مكانتها في الشريعة الإسلامية. 4. بيان أن القرآن الكريم والهدي النبوي ليسه كلاندمًا نظريًا، وإنما هما واقع في الحياة لا بد أن يُعاش، مما جعل لتطبيق نظام الميراث أثر مملوس في ازدهار الأمة الإسلامية. 5. دحض شبا المستشرقين في القضايا والمواقف، والادعاءات التي نسبت إلى الميراث وتوزيعه في الإسلام.

إشكالية الدراسة:

تتضح مشكلة البحث من خلال معرفة قضية ضوابط التشريع الإسلامي في الميراث، وكيفية تعامله مع الحقوق التي تخص الأفراد، وتهدف الدراسة للرد على هذا السؤال: ما هي ضيو ابط التشريع الإسلامي في الميراث، ويتفرع مناه العديد من الأسئلة منها:

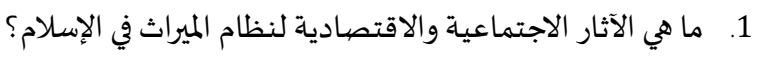

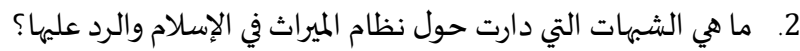

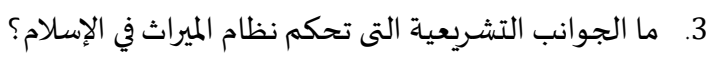

الدراسات السـابقة:

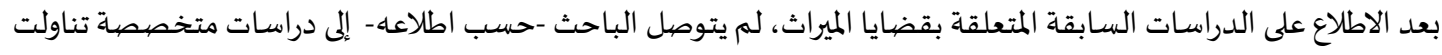
قضية التشريع الإسلامي للميراث أو الحديث عن آثاره الاقتصادية والاجتماعية وشبهاته المعاصرة، ومن الدراسات السابقة المتعلقة بالموضيوع: 
دراسة علي (2015) الأحكام العامة للميراث في الشريعة الإسلامية، والشر ائع الأخرى، دراسة مقارنة، وتختلف عن دراستنا

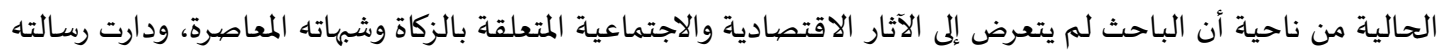
حول الأحكام العامة الواردة في القرآن الكريم والسنة النبوية عن أحنام أحكام ومسائل الزكاة.

منهجبية الدراسة:

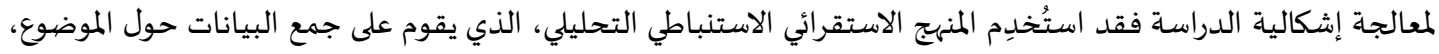

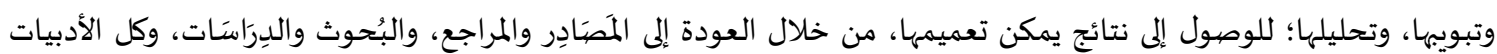

العلمية الحديثة.

بالإضافة إلى تتبع وعرض أهم نتائج الدِرَاسَّات السـابقة؛ للاستفادة منها في معرفة، واستخلاص وتدوين أهم القضايا المتعلقة

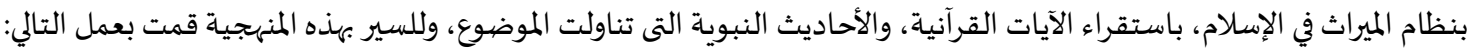

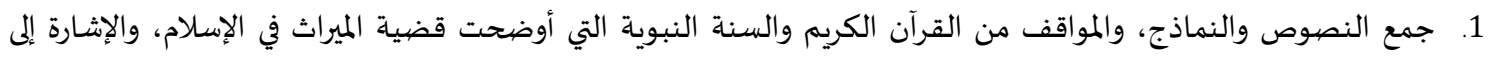
كيفية تطبيقها في مجتمعنا المعاصر.

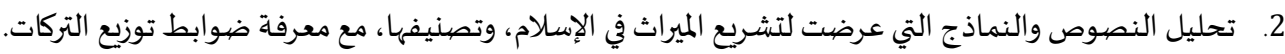
3. عزو الآيات القرآنية بذكر سورها وأرقامها مع كتابتها بالرسم العثماني، حتى تكون بعيدة كل البعد عن الخلل أو التصحيف.

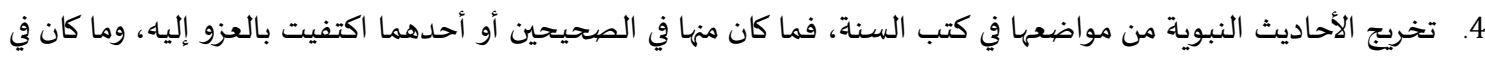

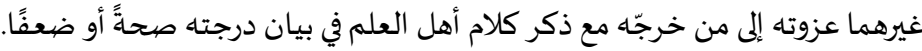
5. إحالة المادة العلمياة إلى مصادرها، معرجها مع التركيز على موضوع البحث، وتجنب الاستطراد، والأقوال والآراء، والمسـائل الغرببة والشاذة. 6. من ناحية العرض آثرت ـ قدر الإمكان ـ سهولة الأسلوب، وتبسيط الكلام، وتوضيح الأحكام، والتركيز على الجوانب العصرية،

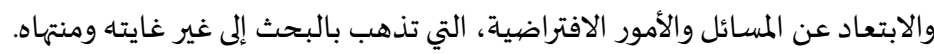

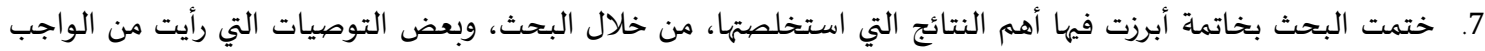

ذكرها. حدود الدراسـة: (n يقتصر البحث على مجموعة أطر أساسية توضح معالمه،، وهي: نظام الميراث في الإسلام، وأسسه وغاياته، وآثاره الاجتماعية والاقتصادية من خلال دراسة آيات القرآن الكريم والسيرة النبوية المطهرة على صاحبها أفضل الصلاة والتسليم. خطة الدراسـة: أما عن خطة الدراسة فقد قسمتها إلى مقدمة، وتمهيد، وأربعة مباحث، وخاتمة.

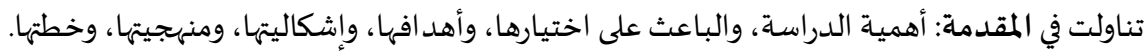

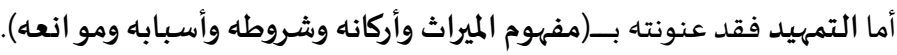

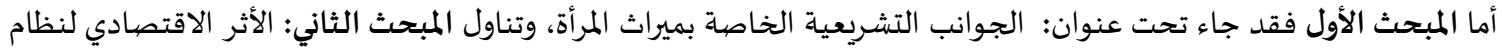
الميراث في الإسلام، وعرض المبحث الثالث: الأثر الاجتماعي لنظام الميراث في الإسلام، وناقش المبحث الر ابع: الشبهات المعاصيرة حول

نظام التشريع الإسلامي في الميراث والرد عليها.

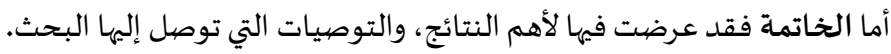

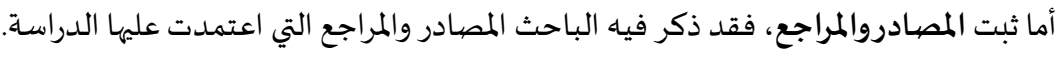

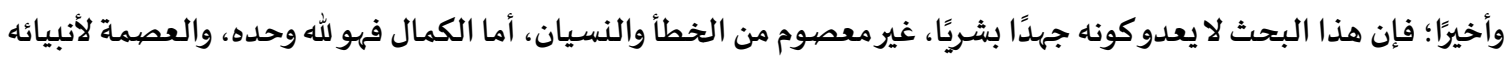

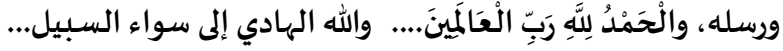

التمهيد: مفهوم الميراث، وأركانه وشروطه، وأسبابه ومو انعه.

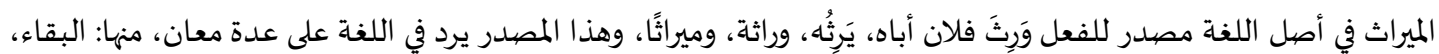

والتد اول، والانتقال، والعاقبة، والبقية (4). 
والميراث والإرث مادة واحدة، وأصل الهمزة فيه واو؛ لأنه من ورث(5)، وورث فلان المال مناه، وعند: يرث وراثة، صار إليه ماله بعد

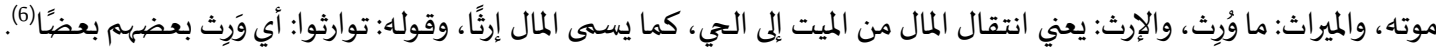

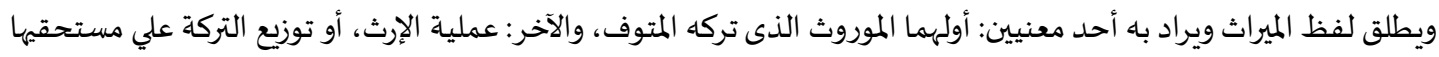

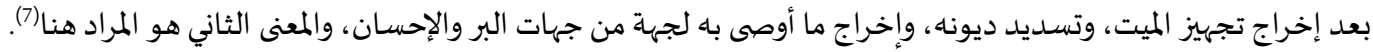

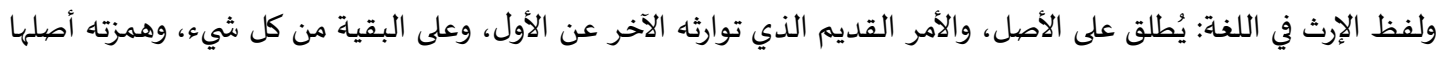

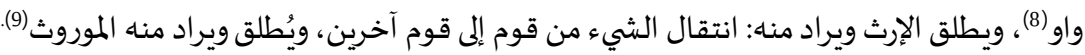
والميراث في الاصطلاح: يُعرف الميراث عند الفقهاء بعدة تعريفات:

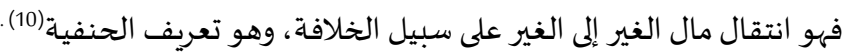
وقيل هو: ما يتركه الميت من كمال أو حق أو اختصياص (11).

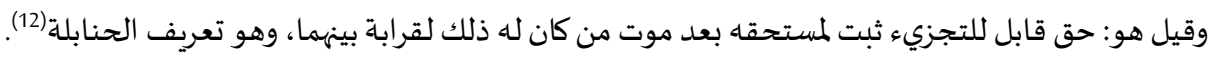
ومن تعريفات الفقهاء للميراث يلاحظ أههم يجمعون على أن الوارث يستحق نصيبه المقدر شرعا بموت المورث، فالورثة

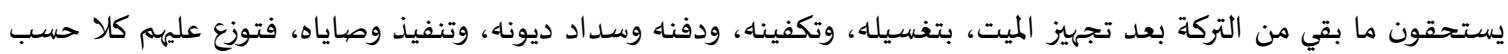

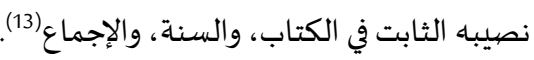

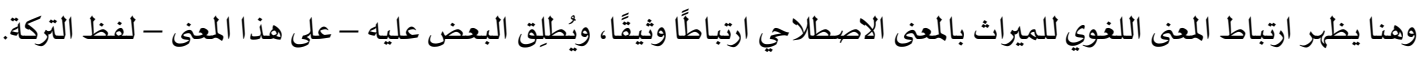

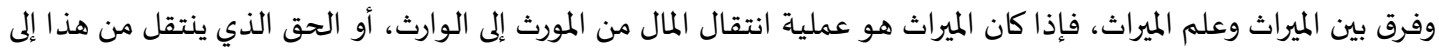

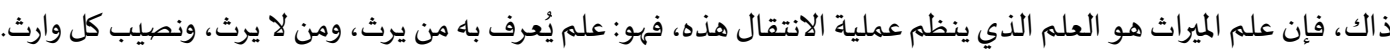

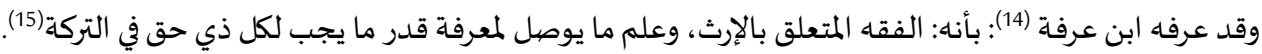
وعلم الميراث مرادف لعلم الفرائض، قال العلامة البقري:" علم الفرائض هو فقه المواريث، والفرائض جمع فريضية بمعنى مفروض، والفرض في اللغة يطلق على عدة معان، منها:(16) التقدير، والقطع، والتحدي، والإنزال، والتبيين، والعطاء، والفرئ والإحلال. والفريضة في الاصطلاح: نصيب مقدر شرعًا للوارث (17).

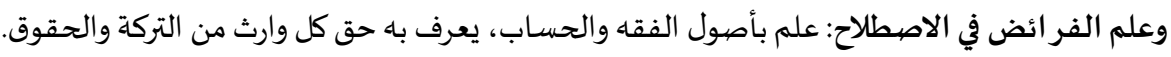
أركان الميراث: الركن في اللغة: هو الجانب الأقوى للشيء الذي يمسكاء ويقوم عليه كأركان البيت الذي لا يقوم إلا بها(18).

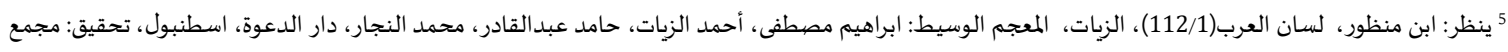

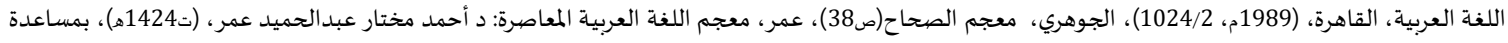

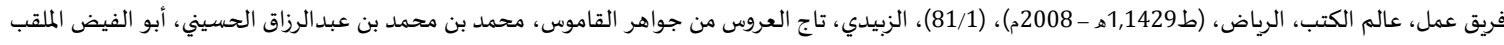

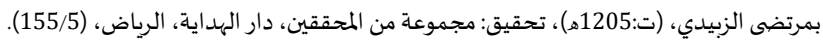

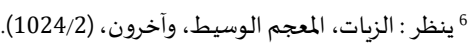

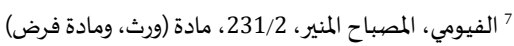
8 الفيروزآبادي، القاموس المحيط، المنر، (16/1) (167/1) 9 الفرضي، العذب الفائض، (16/1)

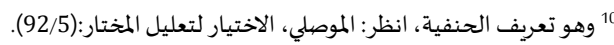

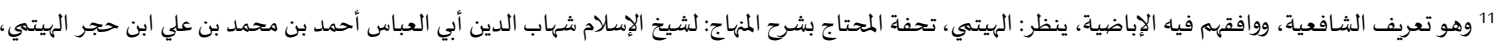

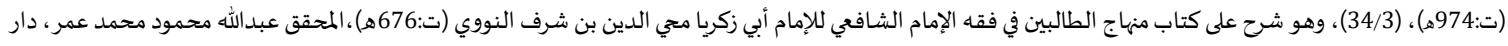

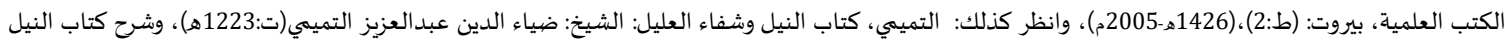

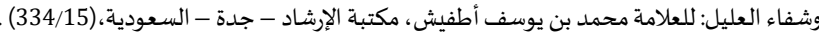
12

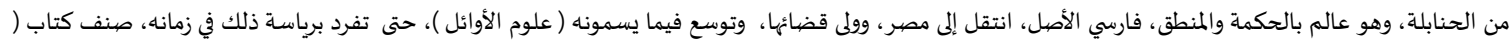

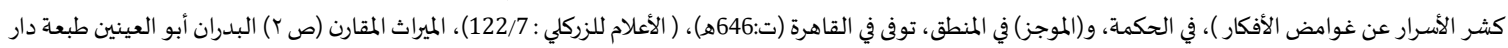

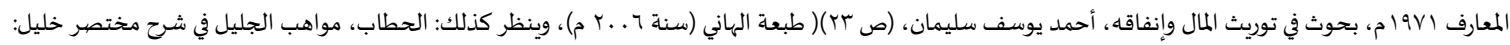

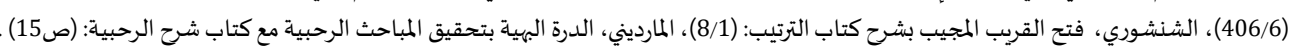

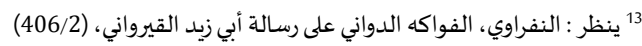

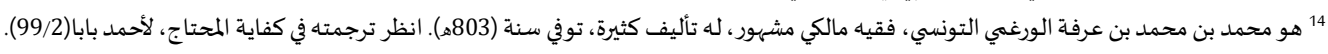

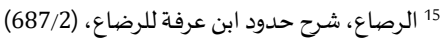

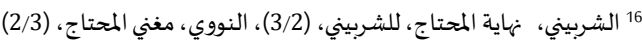

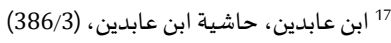
18 2نظر ابن منظور، لسان العرب: (305/5)، الرازي، مختار الصحاح: (صابن (136).

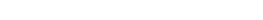


وفي الاصطلاح: ركن الشيء ما يقوم به ذلك الشيء من التقوم، وقيل ما يتم به، وهو داخل فيه بخلاف الشرط، وهو خارج عنه (19).

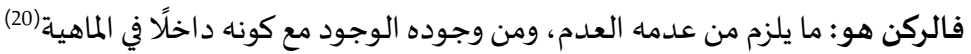

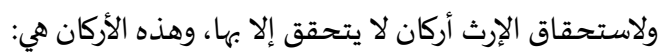

الأول: تحقق موت المورث - حقيقة أو حكما -.

والثاني: تحقق حياة الوارث، وهو الشخص الذيى يمت إلى المورث بصلة القرابة (النسب) أو الزوجية أو الولاء بالعتق.

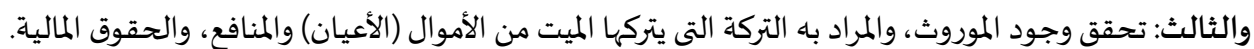

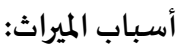

السبب في اللغة: ما كل يتوصل باء إلى غيره، وجمعه أسباب، وسمي الحبل سببا، والطريق سببا لإمكان التوصل بهما إلى

مقصود (21) .

$$
\begin{aligned}
& \text { والسبب في الاصطلاح: ما يلزم من وجوده الوجود، ومن عدمه العدم لذاته (22). } \\
& \text { وقيل: هو عبارة عما يكون طريقًا للوصهول إلى حكم غير مؤثر فياء (23). }
\end{aligned}
$$

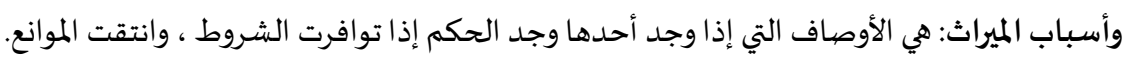

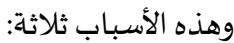

أحدها: الزواج الناتج عن عقد زواج صحيح قائم، ويعتبر في حكم القائم لو حدث طلاقة ، ومات أحداث الزوجين أثناء العدة، وكان

الطلاق رجعيًا.

والثاني: القرابة الناشئة عن وحدة النسب، وتعتبر هذه الصيلة أقوى الصلات، وتشمل أصول المورث كالأب والجد، والأم والجدةة،

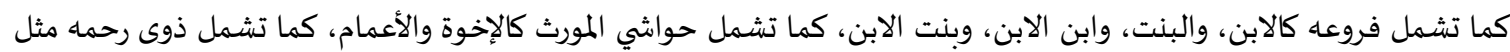

$$
\text { الخال والخالة، والعمة، ونحول فئهم. }
$$

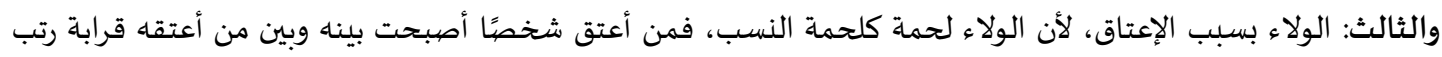

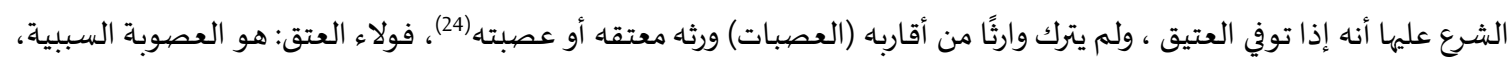

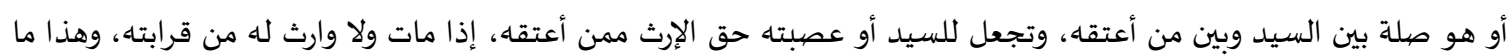

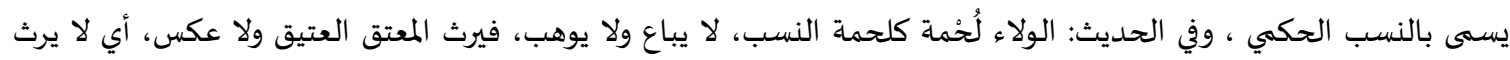

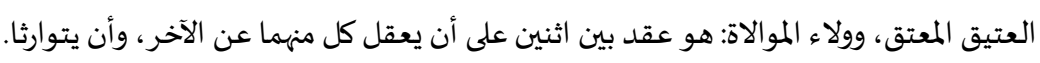

شروط الميراث:

شروط الميراث ثلاثة:

الأول منها: موت المورث حقيقة أو حكما، والموت الحقيقي معروف، أما الموت الحكمي فيُقصد باه حكم القاضي بوفاة المفقود ومن في

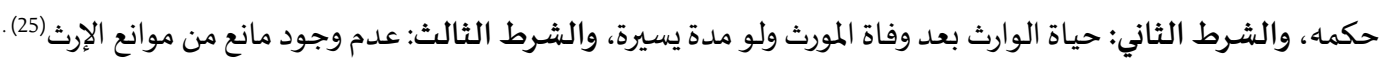
مو انع الإرث:

والمقصيود بمو انع الإرث: هي الأوصاف التى إذا وجلدت بطل الحكم، وهى بالنسبة للميراث ثلاثة:

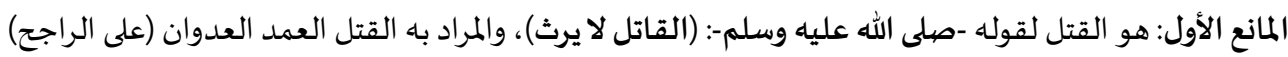

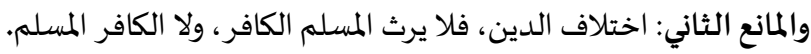

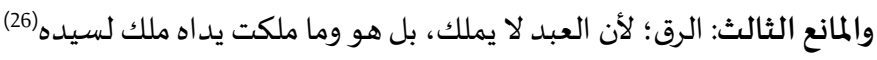

19 ينظر: الجرجاني، التعريفات: (ص117).

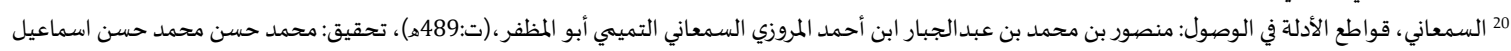

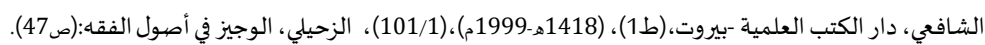

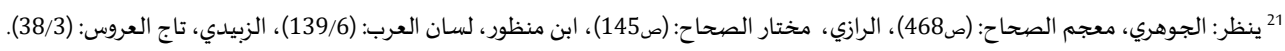

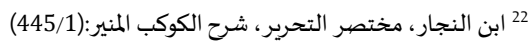

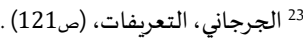

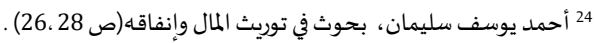
25 (المرجع السابق، (ص 28 أسمد بوسفان، 26 أحمد يوسف سليمان، بحوث في توريث المال وإنفاقه (ص 29، 30).

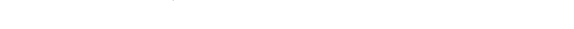


المبحث الأول: الجو انب التشريعية الخاصية بميراث المرأة

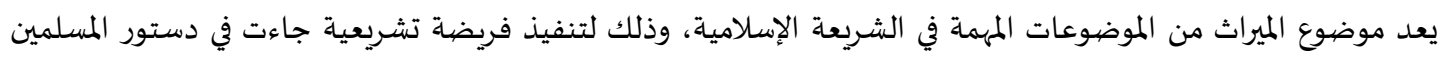

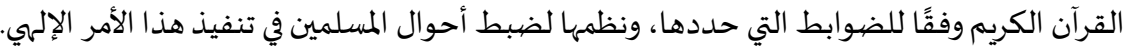

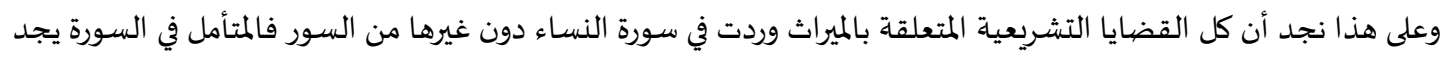

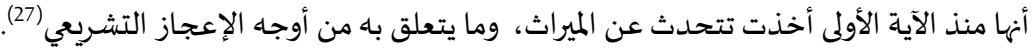

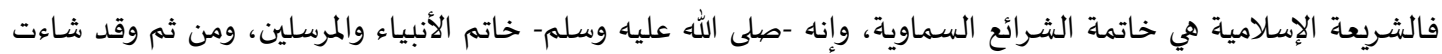

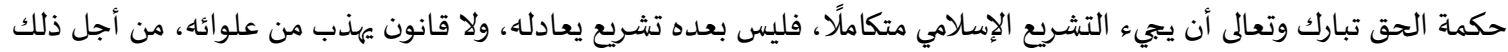

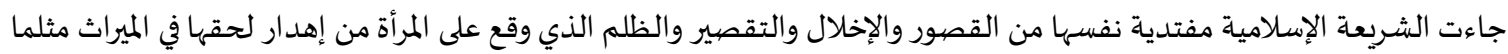

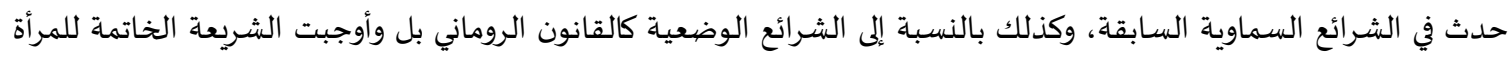

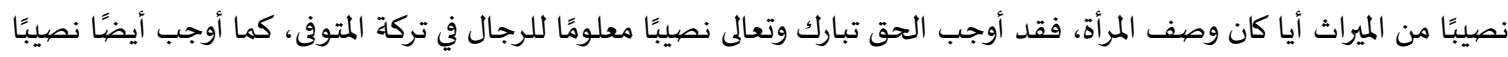

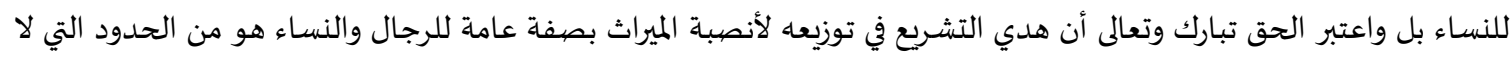

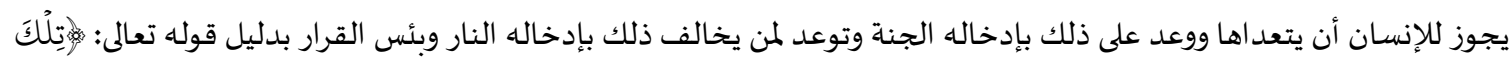

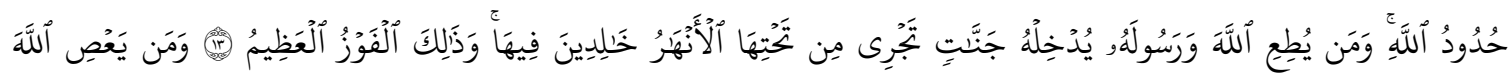

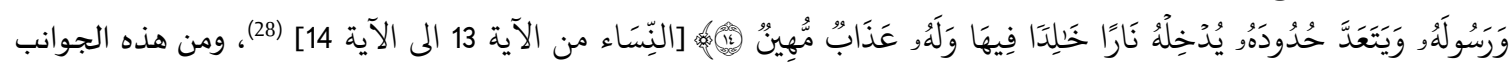

التشريعية:

1. النفس الإنسانية تسعى إلى تنفيذ الميراث كحكم من أحكام الله تعالى:

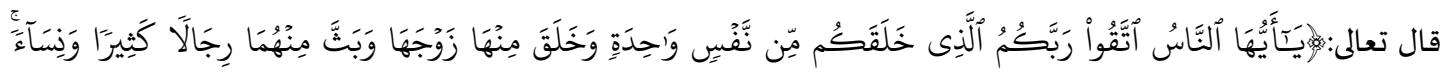

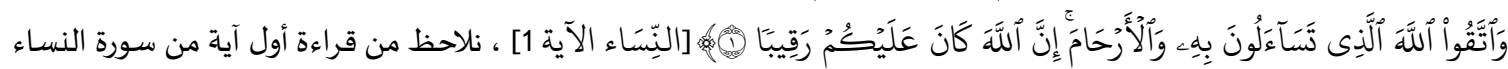

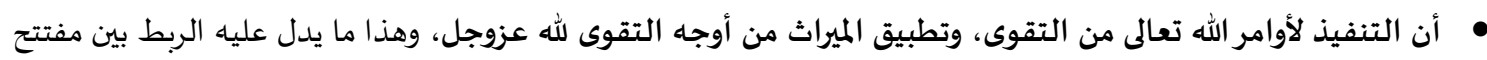

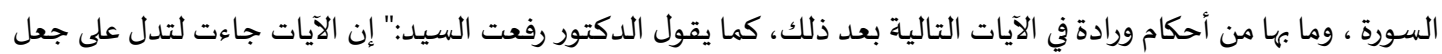

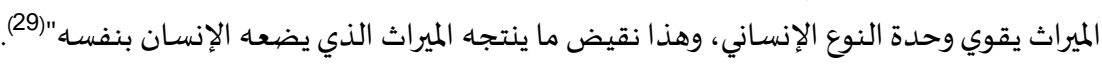

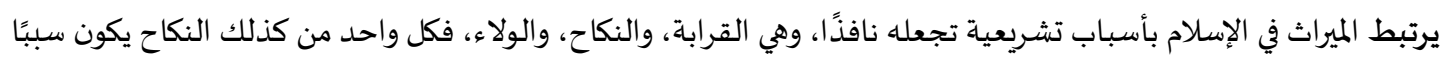

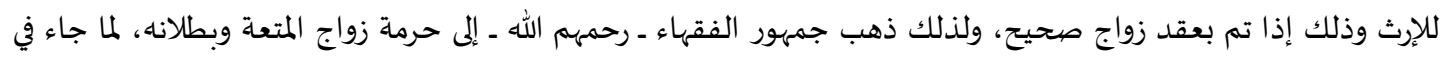

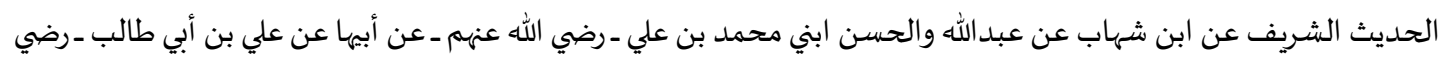

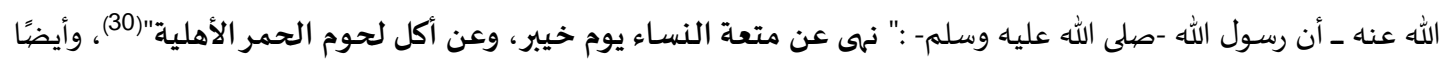

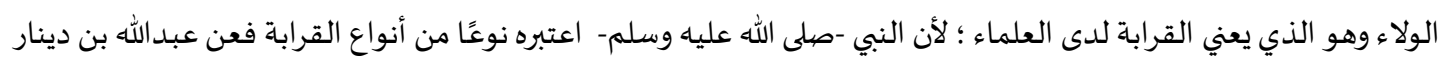

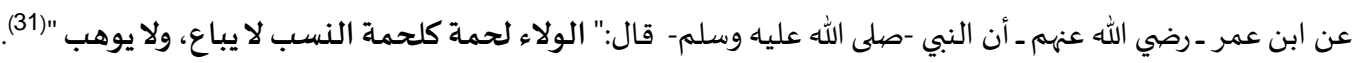

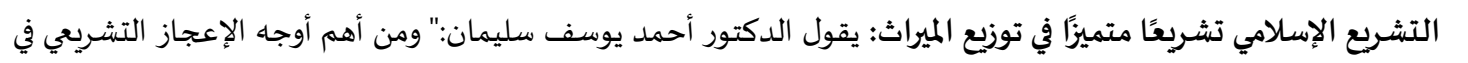

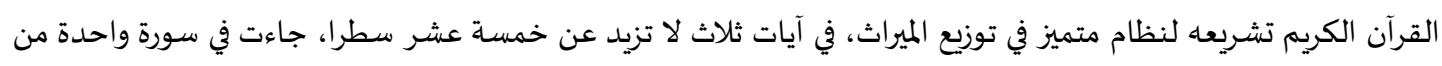

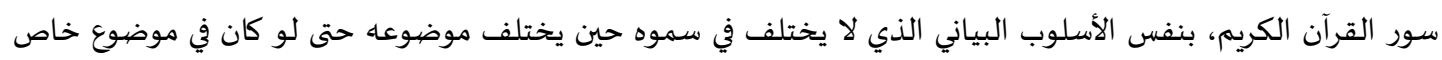

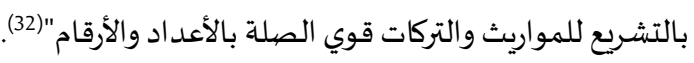

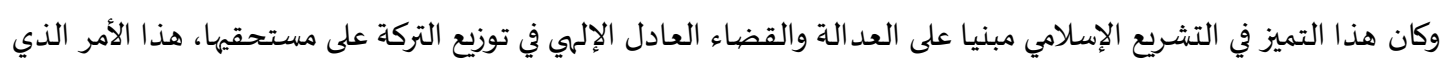

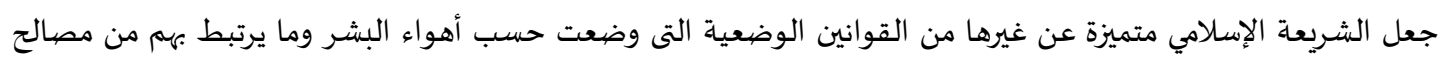

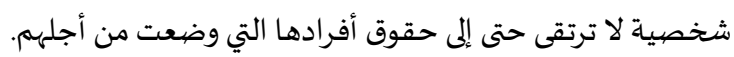

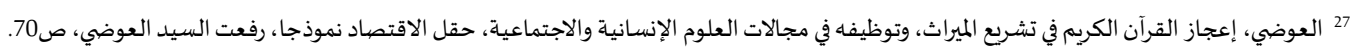

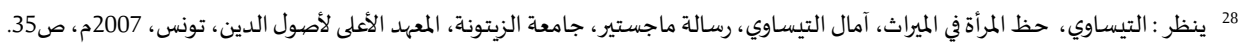

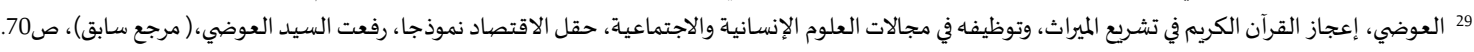

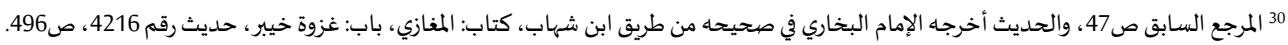

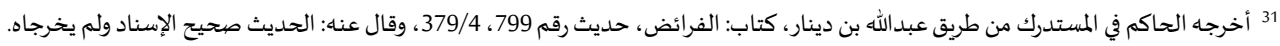

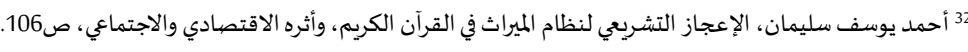


أن الله تولى توزيع هذه الثروات بنفسه بقو انينه هو عزوجل: يقول الدكتور أحمد يوسف سليمان:" تولى الله سبحانه وتعالى الى المان

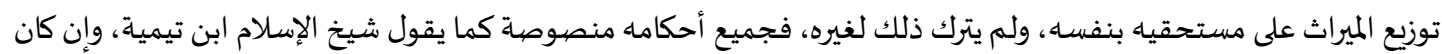

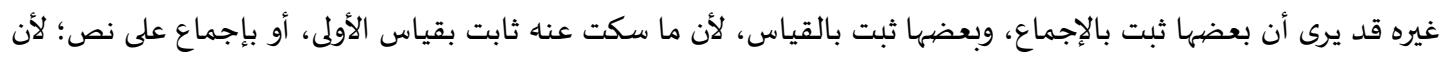

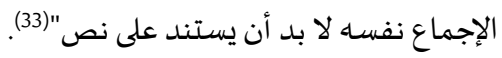

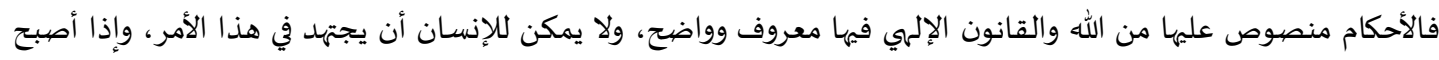

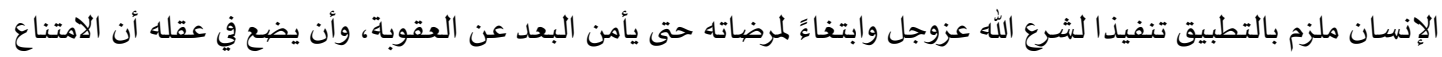
عن تنفيذ هذه الأحكام هي معاداة للمولى عزوجل واعتراضا على قضائه.

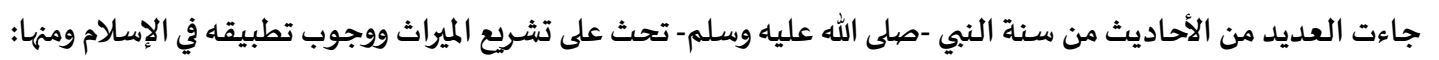

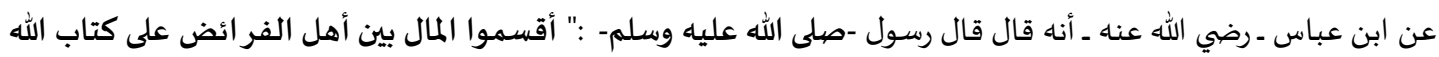

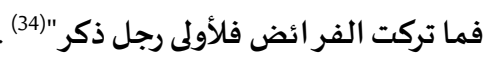

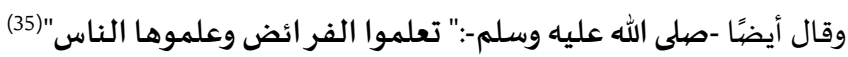

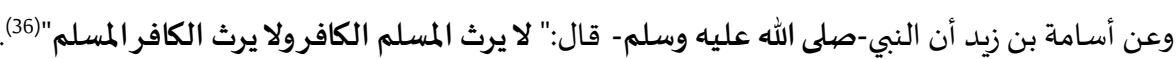

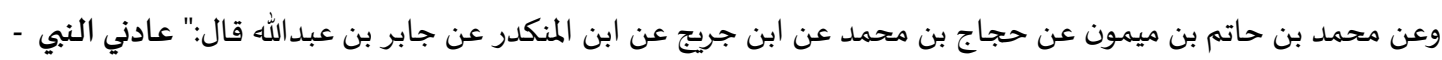

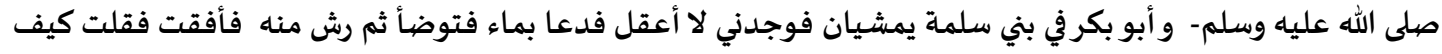

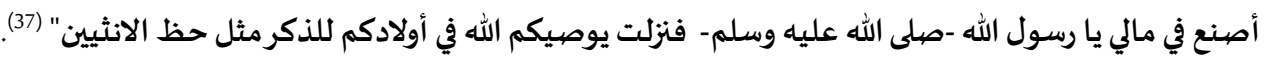
• سدد الديون أولا قبل البدء في توزيع التركة ويجب التأكد من أن تكون هذه الديون، هي ديون فعلية أما إذا كان المقصهود بها الإضرار بالورثة فلا سداد (38)، وهذا من صوزيع التركيم ويجب التشريع الإسلامي.

المبحث الثاني: الأثر الاقتصهادي لنظام الميراث في الإسلام

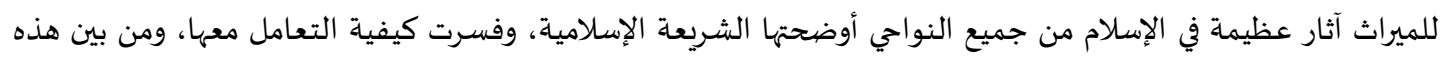

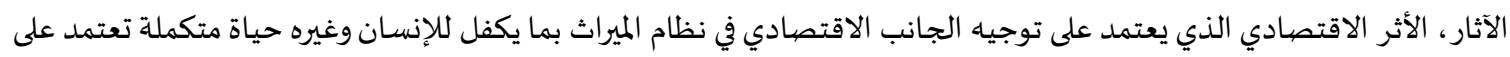

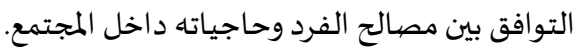
ويتضح أن للميراث في الإسلام العديد من الآثار الاجتماعية، ومنها:

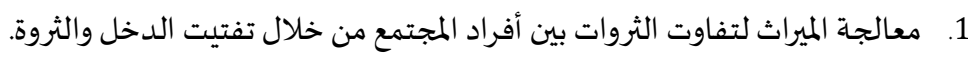

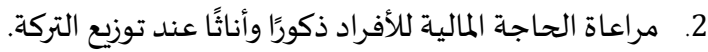

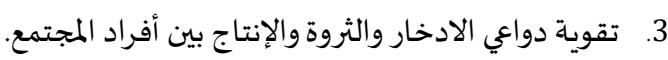

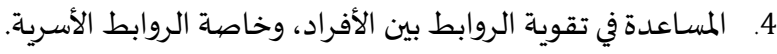

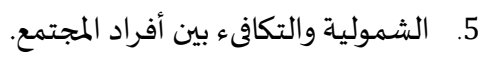

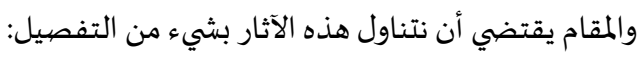

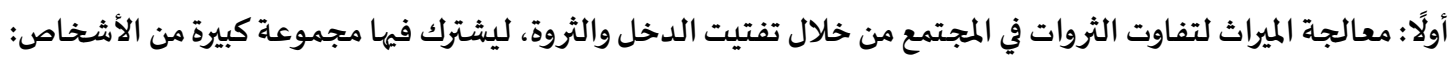

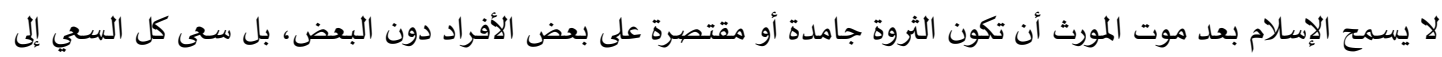

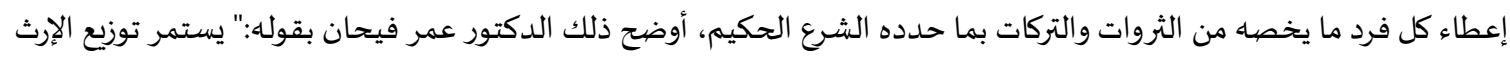

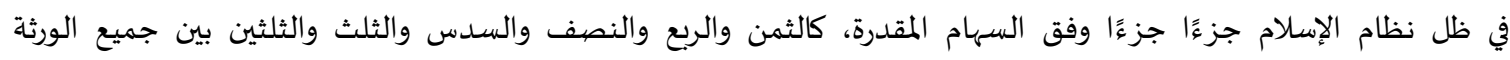

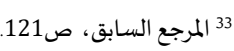

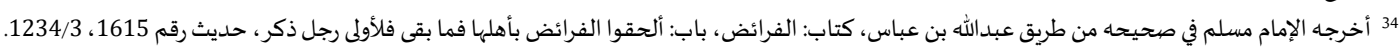

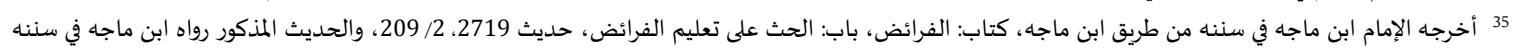

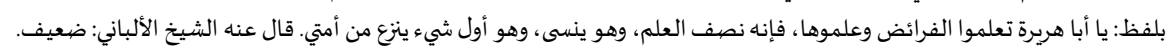

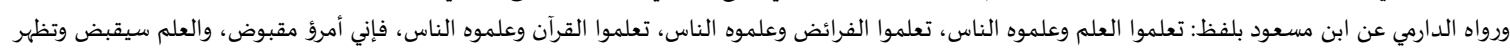

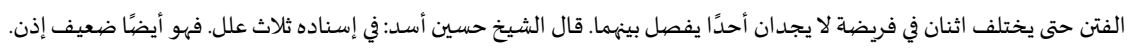

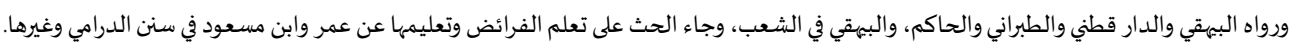

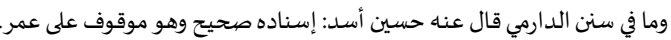

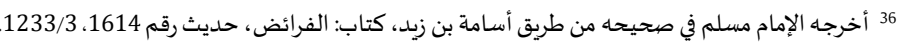

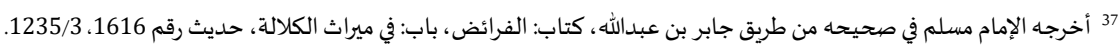

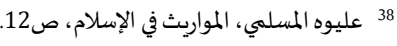




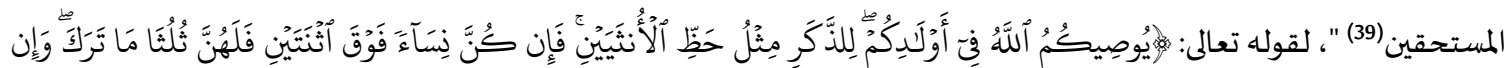

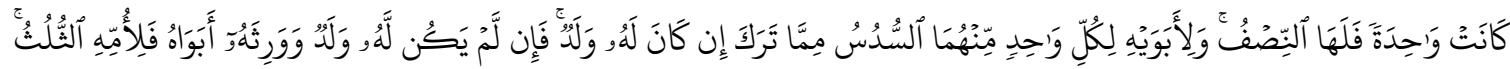

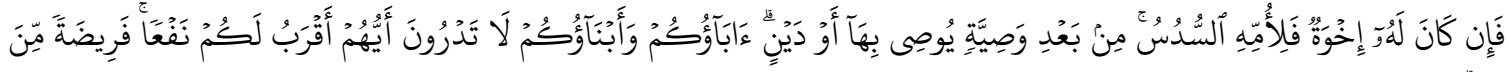

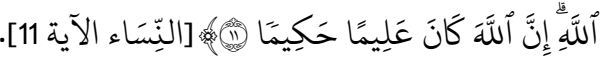

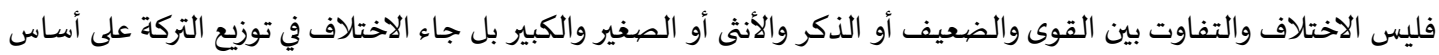

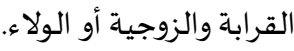

وعلى هذا خالف الإسلام غيره من الأنظمة التي كانت تجعل الميراث كله بيد شخص واحد أو يتنازل عنها الموروث لمن يشاء من

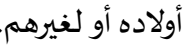
وقضى الإسلام على مظاهر الرأسمالية التي سادت في المجتمع، وقضى معها أيضا على أشكال التسلط، والجور، والظلم، ومن

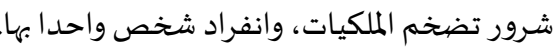
ويمكن القول أن من آثار توزيع التركة في الإسلام وتفاوتها بين الأفراد ما يلي:

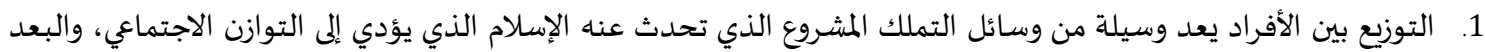
عن الفساد، والإخلال بمنظومة المجتمع. 2. إعطاء كل ذي حق حقه حسب الأنصبة المشروعة في الإسلام، وعلى القواعد المنوطة في ذلك الشأن وتنفيذ الحدود كما أراد الله

عزوجل(40). 3. الابتعاد كل البعد عن المظاهر التي تؤثر في توزيع الميراث بين الوراثيين كالبيع الصوري والحيل الممنوعة، ولا بد أن يتذكر من

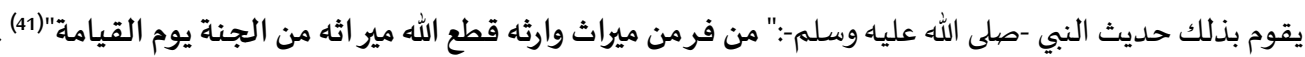

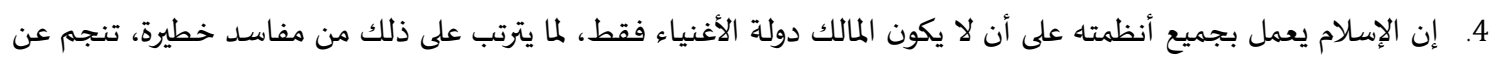

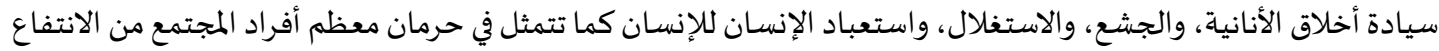

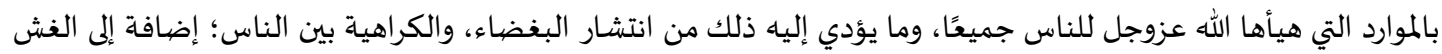
والكذب والرشوة وأكل أموال الناس بالباطل (42).

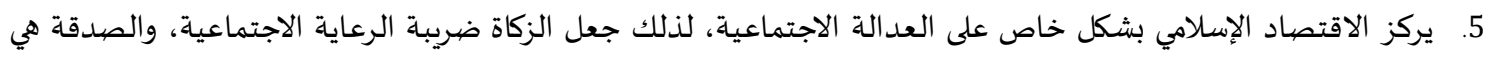

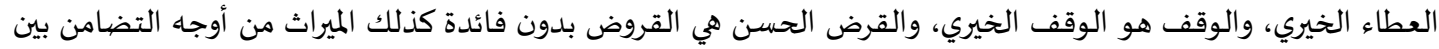

أفراد المجتمع (43). 6. أوضح الدكتور أحمد يوسف سليمان:" قضية تفيتت الثروة من نظام الميراث في الإسلام لها مظاهر منها تقسيم التركات أثلاثًا

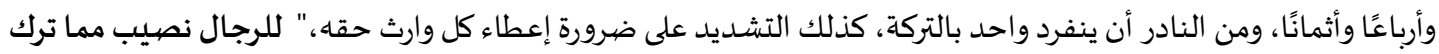

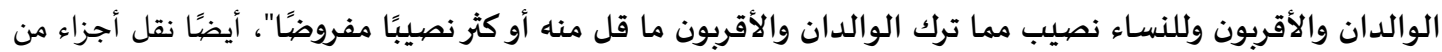

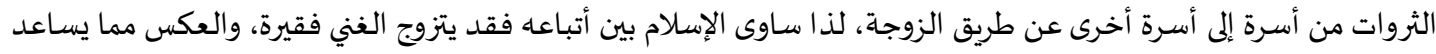

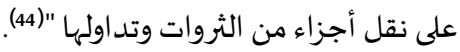

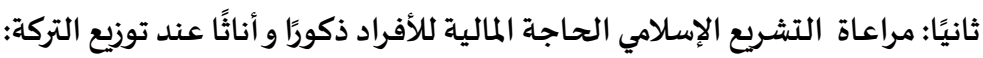

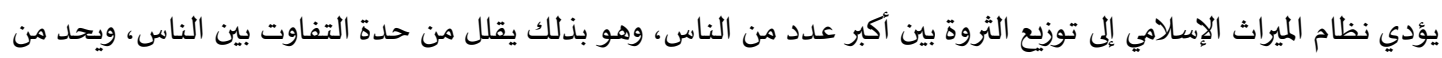

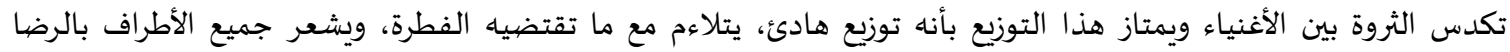
والاطمئنان نتيجة لهذا التوزيع (45).

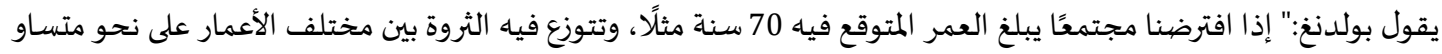
فإن 70/1 من الثروة ستنتقل بعد الموت والإرث كل سنة فإن كان معامل الدخل إلى رأس المال يقارب فإن الثان الثروة ستنتقل بالإرث تولد الثالد

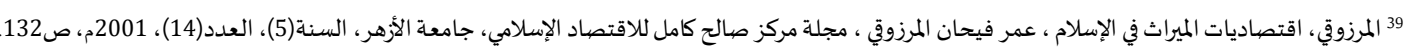

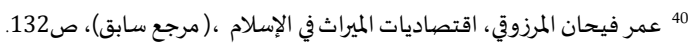

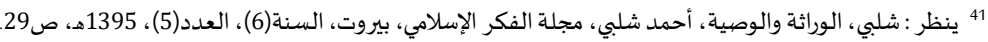

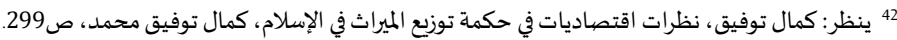

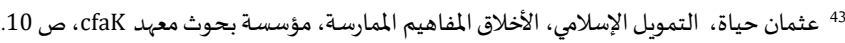

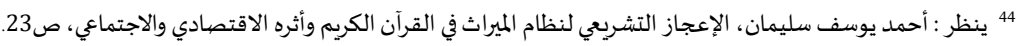

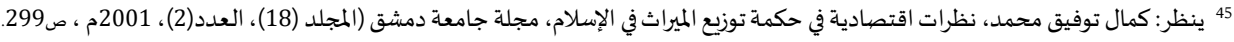


حوالي 70/3 أي 4\% تقريبًا من الدخل كل سنة، ولما كان المسنون أغنى من الأحداث فإن النسبة ستكون أعلى من ذلك ربما تبلغ 8-10\%

كما يقول وليم سميث:" تعمل أحكام الإرث الإلزامي في الإسلام كوظيفة توزيع أخرى واستنادًا إلى المصادر القرآنية تشكل هذه

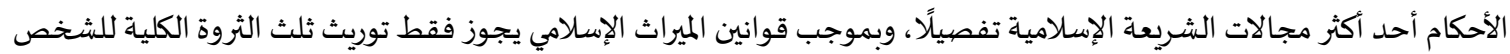

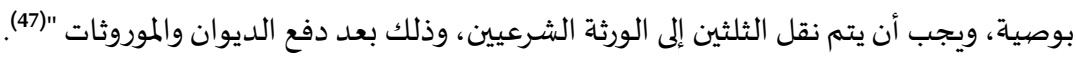

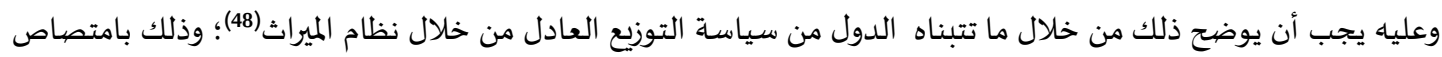
جزء من دخول الطبقات التى زادت دخولها بالتضخم.

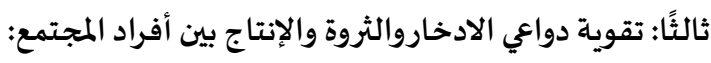

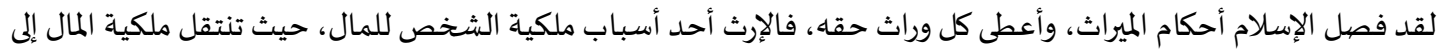

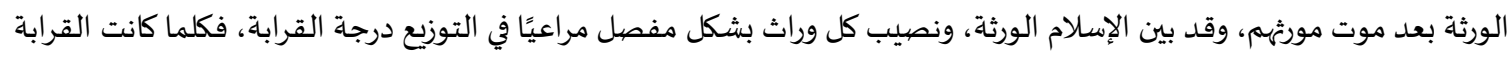

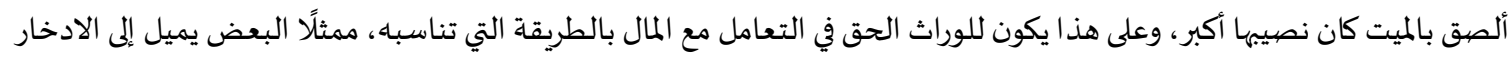
والثروة دون التطرق للاستفادة من المال الاستفادة الأمثل.

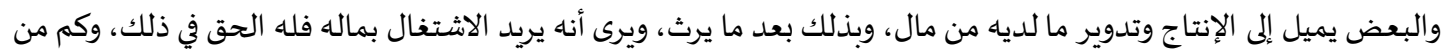

شاب من شباب الوطن يعتمد على ميراثه في عمل مشروع يبدأ به حياته (49). فيعد نظام الإرث وسيلة نقل للملكيات والحقوق والثروات وإعادة توزيعها بشكل منسق هئس هادئ مقسم بطريقة نظامية وزمنية تتناسب مع حياة البشر، ومتطلباتهم المعيشية والنفسية كما يعتبر حافزا من حوافز التنمية الاقتصادية بما يسمح بإكمال دورة العطاء والإعمار المكلف بها البشر.

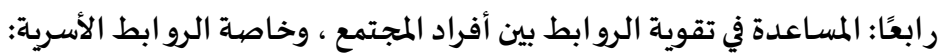

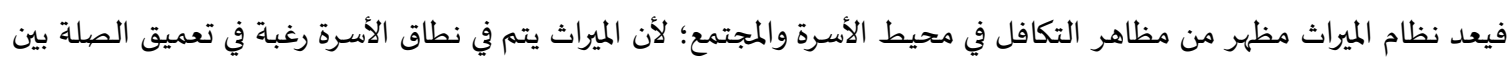

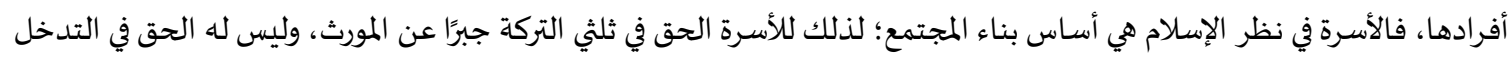
لتقييد الأنصبة أو تحديد المقادير (50). ومما يدل على ذلك قول النبي -صلى الله عليه وسلم-:" إنك أن تدع ورثتك أغنياء خير من أن تدعهم عالة يتكففون الناس" (51)

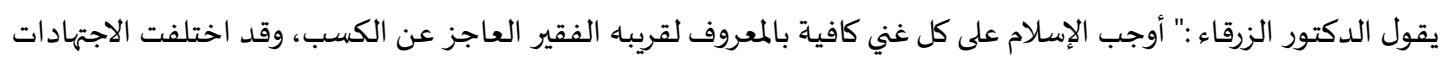

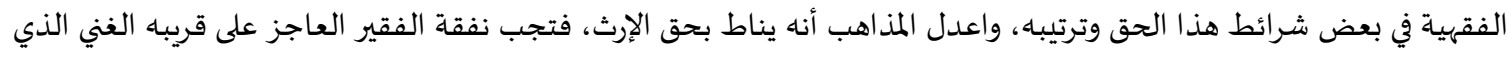

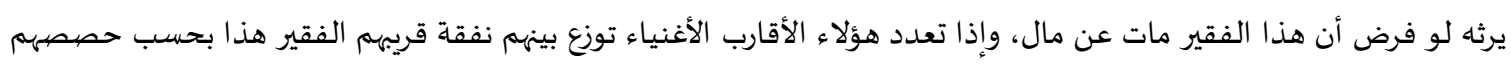

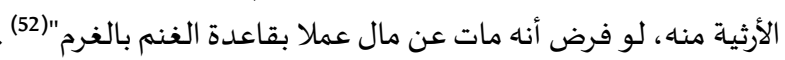

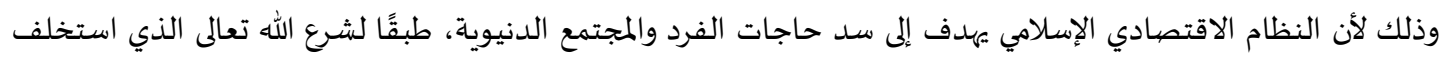
الإنسان في التصرف في المال والانتفاع به، فالمسلم يدرك أن المال ملك لله ـ عزوجل ـ فيكون إرضاء مالك المال هدفًا يسعى إليه المسلم

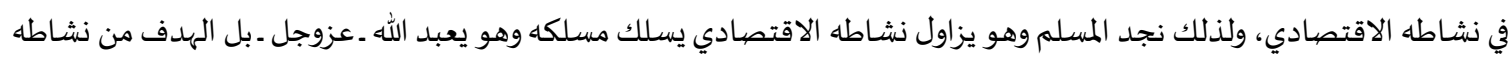
أساسا عبادة الله تبارك وتعالى (53.). فإن قواعد الميراث في الإسلام تهدف إلى الحفاظ على الأسرة الممتدة، وليست نواة الأسرة الأساسية وهكذا، في حالة عدم وجود

أحفاد مباشرين، يتم تحديد حصص عشرية لمختلف مجموعات الأقارب الباقين علي قيد الحياة، كورثة شرعيين لثروة المتوفى (54).

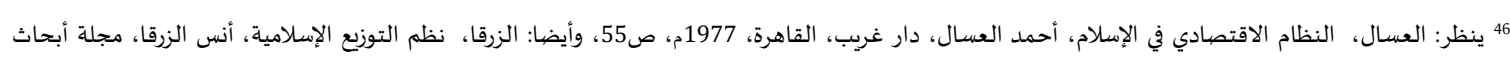

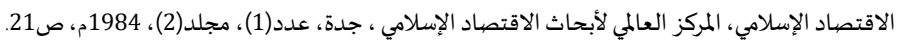

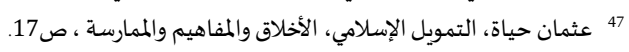

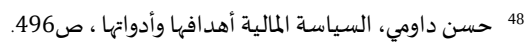

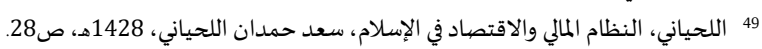

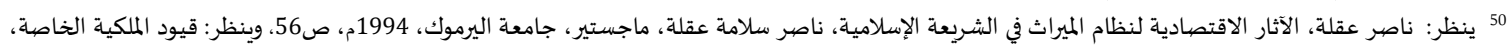
المصلح، ص299. 51 أخرجه البخاري في صحيحه من طريق سعد بن أبي وقاص، كتاب: الوصايا، باب: أن يترك ورثته خيرا من أن يتكففوا الناس، حديث رقم 2742، 3/4.

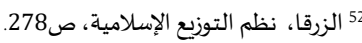

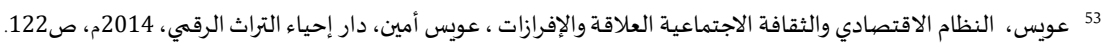

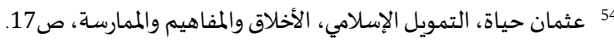


خامسًا: الشمولية والتكافوء بين أفراد المجتمع:

يتميز قانون الميراث الإسلامي بطابعه الشامل والمتكافئ؛ لكنه لا يخلو من الخلاف والاجتهاد في مناقشة القضيايا التي تخص الميراث بالشكل الذي يتناسب مع أفراد المجتمع.

لذا عالج الإسلام عن طريق نظام الميراث نظام الطبقية، وجعل المال والتركات غير مقصيور على شخص بعرئه بعينه، وهذا الأمر

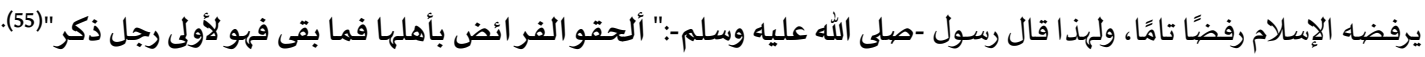

\section{المبحث الثالث: الأثر الاجتماعي لنظام الميراث في الإسلام}

جاءت أحاديث النبي -صلى الله عليه وسلم- تحمل دلالات كثيرة واضحة على أهمية الميراث وأثره في تقوية الجانب الاجتماعي بين أفراد المجتمع، روى مسلم عن ابن عباس رضي الله عنه أنه قال قال رسول الله -صلى الله عليه وسلم-:" " أقسموا المال بين أهل

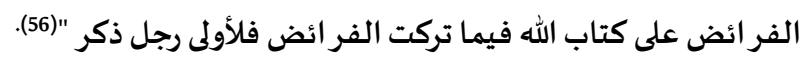

ومن دلائل الحديث:

1. ضرورة تقسيم المال بين أصحاب الفرائض ـ المستحقون للميراث ـ فيه دلالات واضحة على العدالة والترابط بين أفراد الأسرة

$$
\text { الواحدة في المجتمع. }
$$

2. جعل الإسلام حق الذكر أكثر من حق الأنثى أحيانا، وذلك مراعاة للأعباء المجتمعية التي تقع عليه من الإنفاق على الأسرة والأهل

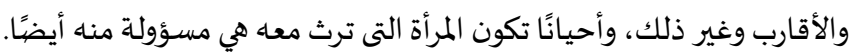

3. الحديث جاء بفعل الأمر الدال على التقسيم، وبالتمعن نجد أن الرواية احتوت على نظرة أخلاقية في المجتمع، وهي تقدير

$$
\text { الإسلام للأفراد والأسرة الواحدة. }
$$

وفي رواية أخرى قال رسول الله -صلى الله عليه وسلم-:" تعلموا الفر ائض وعلموها الناس" (57).

وفيها من الدلائل:

4. الحث على تعلم الفرائض حتى تسود روح التعاون، والتكامل بين أفراد المجتمع فى تحقيق المقصد الإلهي من ضرورة توزيع الميراث.

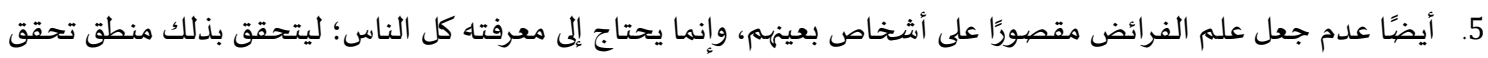

$$
\text { روح التعاون، والود، والطمأنينة بين أفراد المجتمع . }
$$

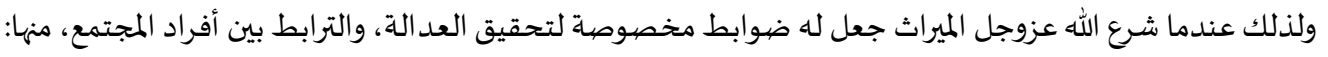

• • مسداد الديون:

سداد ديون المتوفى قيمة اجتماعية كبيرة حث عليها الإسلام أولًا؛ لأن السـاد يكون من ماله الذي تركه قبل موته، وثانيًا: البعد

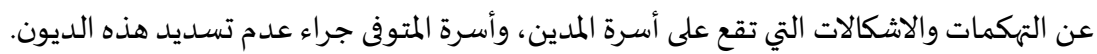

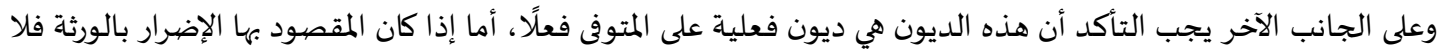

\section{تنفيذ وصبية المتوفَّى لها آثار اجتماعية عظيمة.}

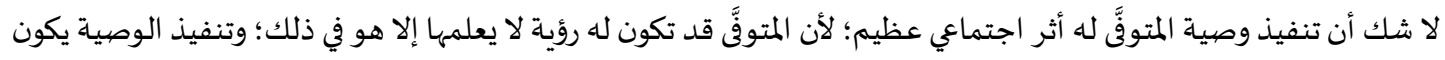

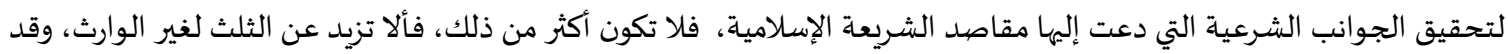

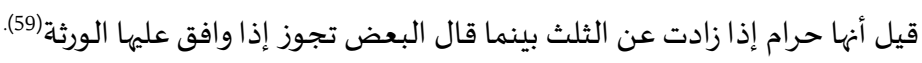

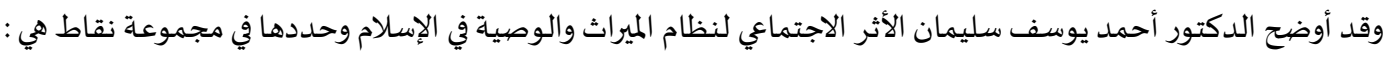
1. التقارب بين الطبقات، وذلك منعا لتكدس الثروة في يد أشخاص بعينهم، فالغني اليوم بعد جيل أو جيلين تنتقل ثروته إلى أولاده، وأحفاده، وأقاربه، وينتقل الميراث من شخص إلى شخص، ومن ون جيل إلى جيل، وتنتقل الثروات حتى يمسي من كان فقيرًا غنيًا

بإذن الله تعالى (60).

ألمرجه الإمام مسلم في صحيحه من طريق عبدالله بن عباس، كتاب: الفرائض، باب: ألحقو الفرائض بأهلها فما بقى فهو لأولى رجل ذكر، حديث رقم 1615، 1233/2، وينظر:

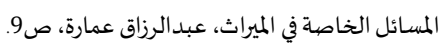
28

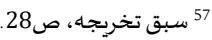

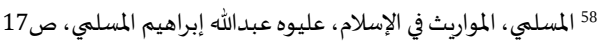
59

60 أحمد يوسف سليمان، الإعجاز التشريعي لنظام الميراث في القرآن الكريم، وأثره الاقتصادي والاجتماعي، ص127. 


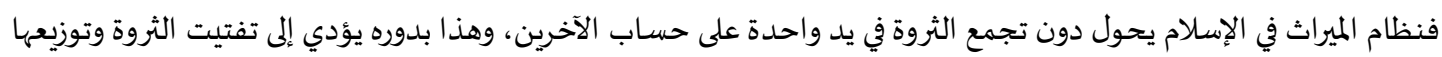

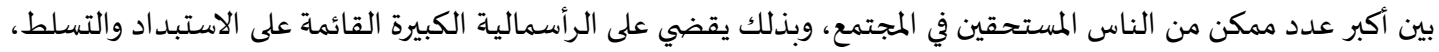

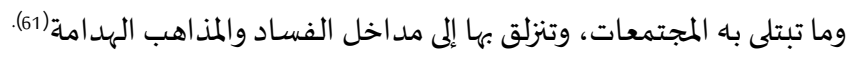

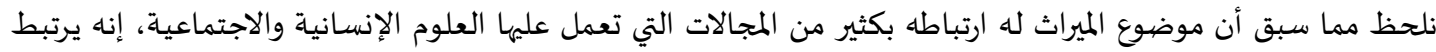

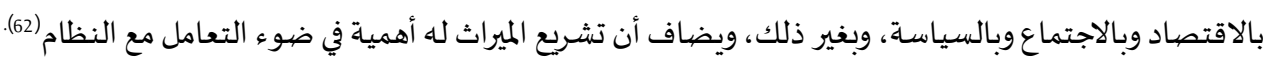

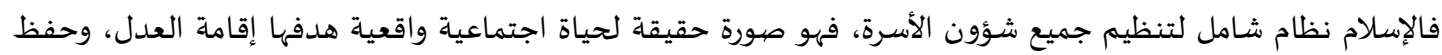

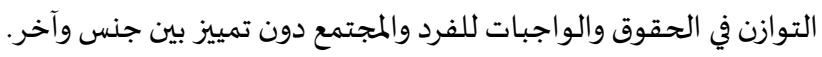

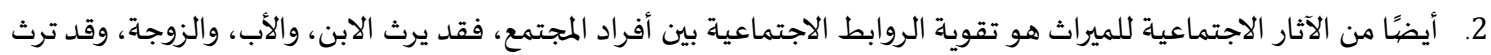

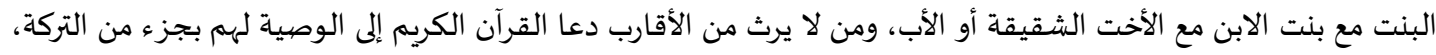

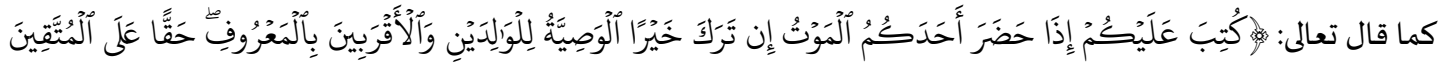

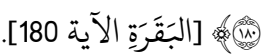
وكذلك من ليس له الحق في الميراث دعا الإسلام (63) إلى إعطائه جزءًا من ذلك حتي يشاركوا الورثة في نعمة المال، قال الله تعالى :"

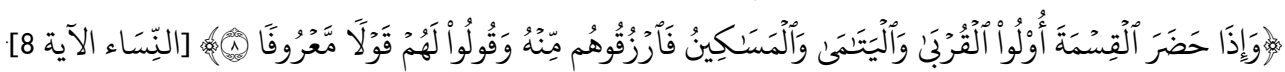

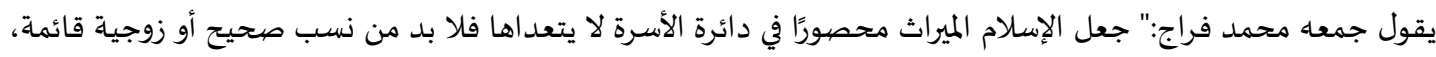

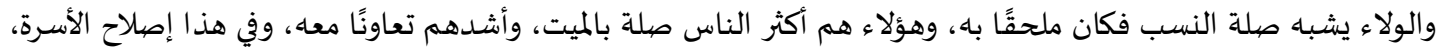
وإحكام الروابط بين أفرادها، وتقوية أواصر المودة فهها، وجعلها متعاونة على تحقيق الخير والسعادة في حياتها، ومن هنا أبطل التلا

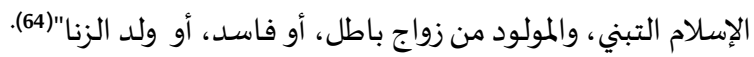

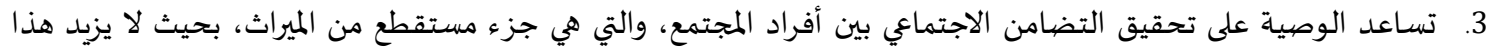

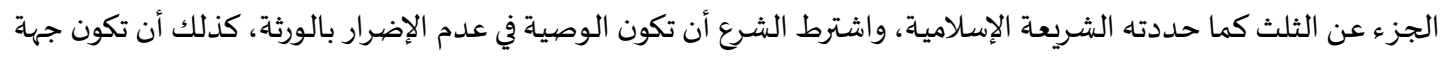
من جهات البر المعروفة والوصية لها غايات قد يريد الإنسان بعد ماته الوصيول إلهيها، منها: تحقيق وجه من وجوه البر التي حددتها الشريعة الإسلامية.

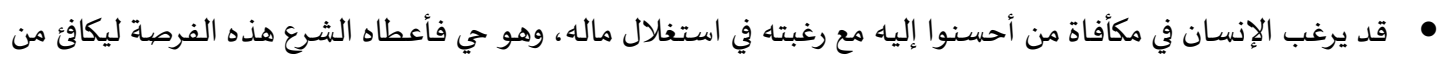
أحسنوا إليه بعد وفاته واستمتاعهم بهذا المال طوال حياتهم.

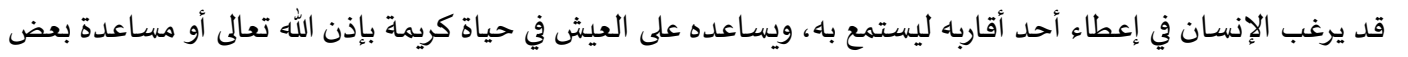
أبناء مجتمعه الفقراء، كما كان يساعدهم في حياته. تسههم الوصية أحيانا في استمرار المؤسسات الاجتماعية في القيام بدورها المنوط لها داخل المجتمع من تعليم وكفالة أيتام، وغير ذلك (65).

يقول الدكتور رفعت العوضي:" إن الإسلام لم يقف بتنظيماه لتوزيع الثروات بين الأفراد عند أحكام الميراث، وإنما أكمل ذلك الكان

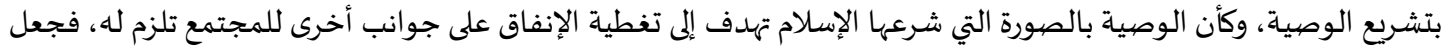

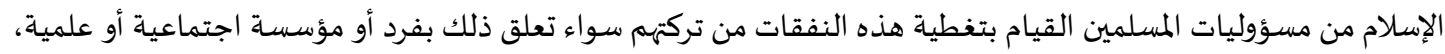

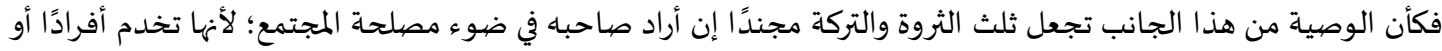
جهات أخرى غير الورثة الأصليين المعروفين "(66).

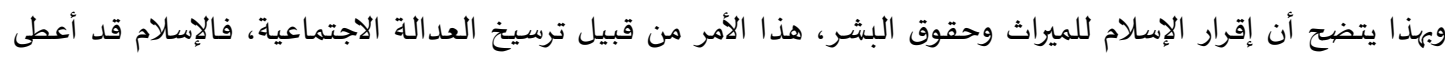

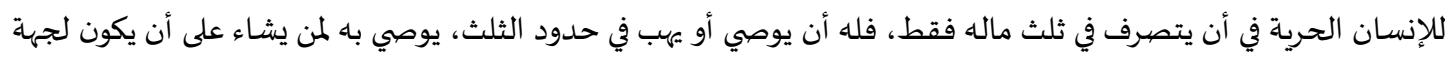

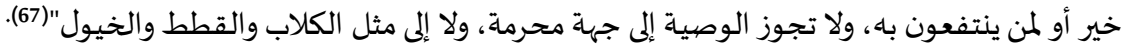

61 جمعاة براج، أحكام الميراث في الشريعة الإسلامية، ص 644

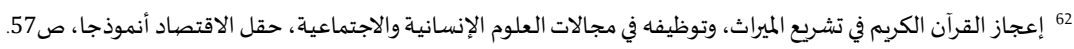

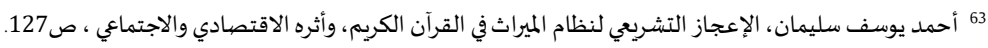

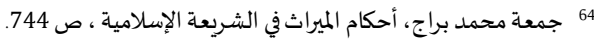

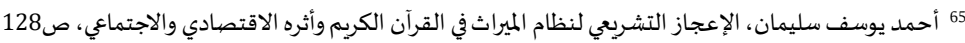

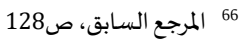

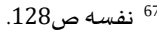


4. من الأمور التي تساعد على التضامن الاجتماعي هناك من القوانين المعاصرة التي صرحت بجواز الوصية الواجبة، وذلك لأسباب

معينة منها: من الامور التئ

إن من الضرورات الواقعية، والمقاصد الشرعية الملجئة للوصية الواجبة في أحوال كثيرة يموت الشخص في حياة أمه وأبيه

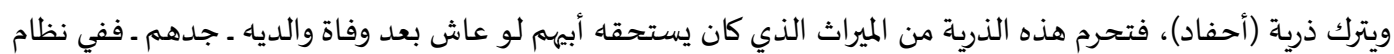

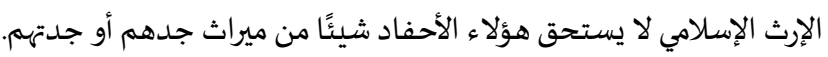

•ليس هناك في الميراث تفضيل للرجل على المرأة كما تذهب بعض الكتابات، وإنما هي مرتبطة بتصور اقتصادي وبناء

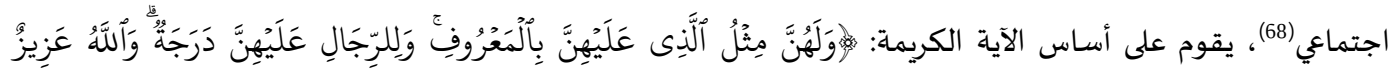

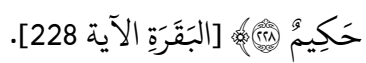

وليست الوصية الواجبة هنا للتفضيل؛ ولكنها لمحاولة التكامل، والتساوي بين أفراد عائلة المتوفى الذي قد يكون في عائلته عنصرًا لا يملك بقدر ما يرث، ويملك الآخرون.

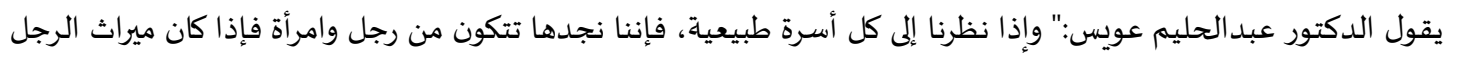

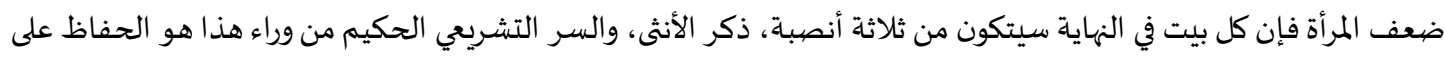

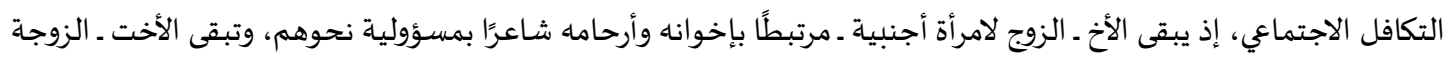

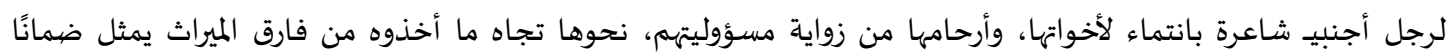

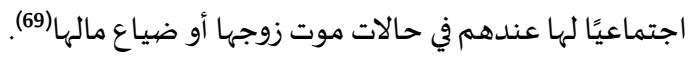

\section{المبحث الر ابع: الشبهات المعاصرة حول نظام التشريع الإسلامي في الميراث والرد عليها}

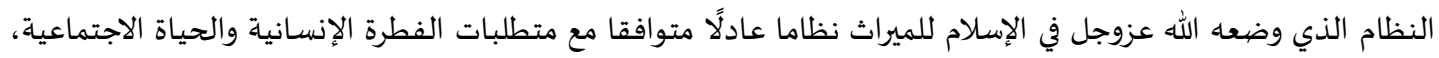

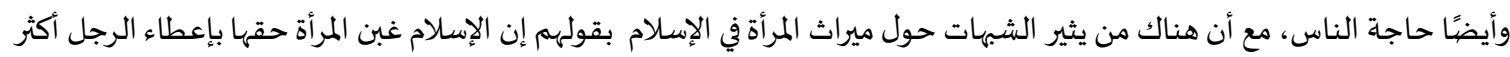

منها، ولم يساو بينهما.

فقد كثر الجدل في الآونة الأخيرة حول حق المرأة في الميراث، وأثيرت الشبهات على ذلك من أعداء الإسلام، ومن المفتونين بهم من

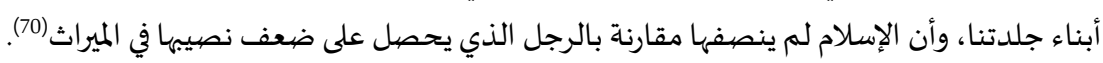

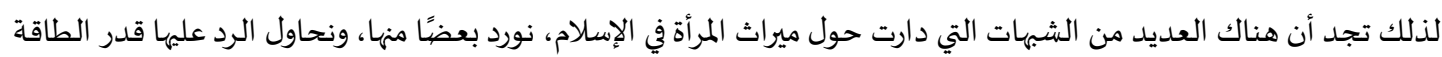

بحول الله:

1. 1 الشبهة الأولى:

نص الشبهة: المساواة بين الرجل والمرأة في الميراث(71)

يرى دعاة المساواة في شتى مناحي الحياة ضرورة المساواة بين الرجل والمرأة في الميراث، حيث أُخذ المّل على الإسلام من قبل فيل

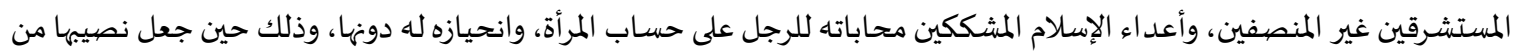

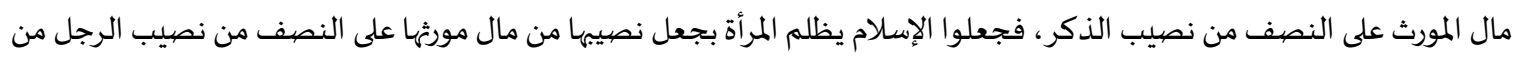
مال المورث نفسـه (72). والرد على ذلك: مال

ترتبط الأحكام الشرعية الخاصية بالمرأة والرجل في نظام الميراث بمدى المصلحة، فيسوى بينهما حيث تكون المساواة هي منطق الفطرة الصحيح، ويفرق بينهما حيث تكون التفرقة أيضا هي منطق الفطرة الصحيح. أن الأساس الذي بني عليه الإسلام هو التفريق، وليس التفضيل بين نصيب الرجل والمرأة في الميراث. أوضحت الشريعة الإسلامية أن موقع الجيل الوارث من التتابع الزمني للأجيال، فالأجيال التي تستقبل الحياة، وتستعد لتحمل

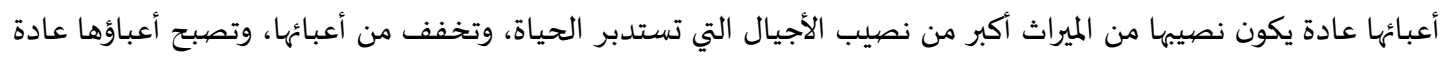

68 الاعجاز التشربعي في القرآن الكريم، ص6690.

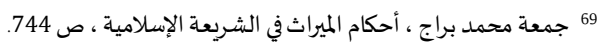

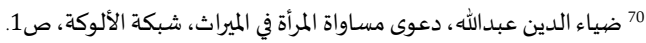

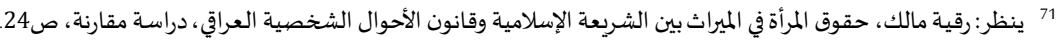

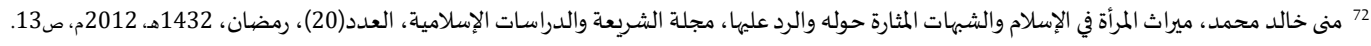


مفروضة على غيرها، وذلك بصرف النظر عن الذكورة والأنوثة للوارثيين والوارثات فبنت المتوفى ترث أكثر من أمها، وكلتاهما أنثى،

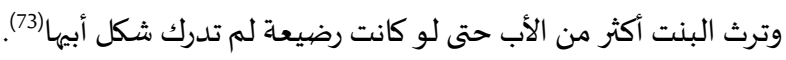

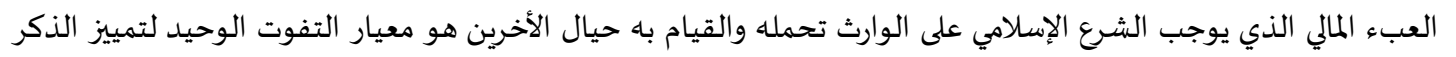

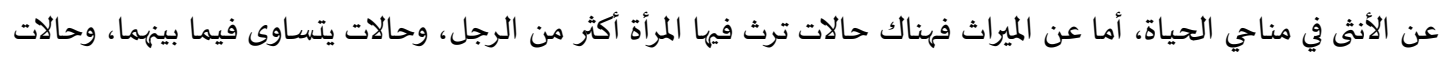

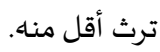
فهناك أربع حالات ترث فهيها المرأة نصف الرجل، وهناك عشر حالات ترث فيهه المرأة أكثر من الرجل، وهناك ثلاك ثلاثين حالة تأخذ

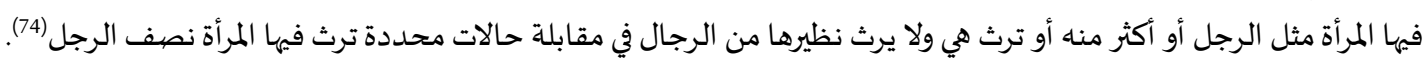

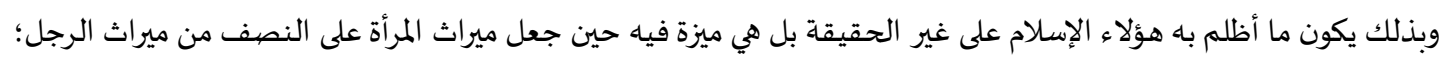

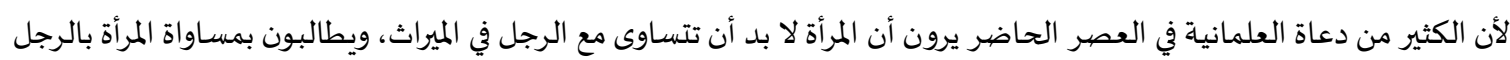

في الميراث في كل الحالات التي ترث فيها (75).

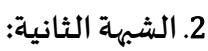

نص الشبهة: عدم إنصاف الإسلام للمرأة في جعل ميراثها أقل من ميراث الرجل:

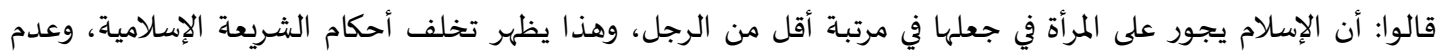
مسايرتها للمدينة الحديثة.

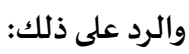

إن الأصل في التفريق بين ميراث الرجل والمرأة في الإسلام مبني على الإنفاق والمسؤول عنه هو الرجل، فحين قرر الإسلام إعطاها

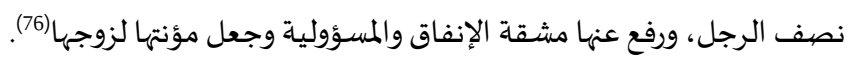

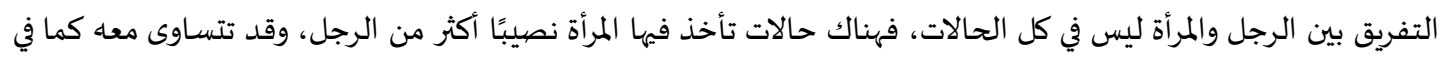

$$
\text { ميراث الأخوة، والأخوات لأم. }
$$

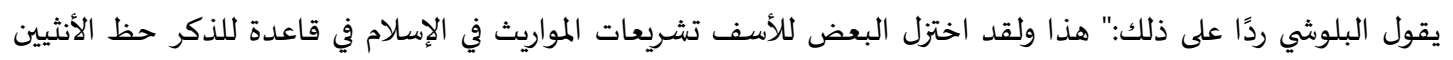

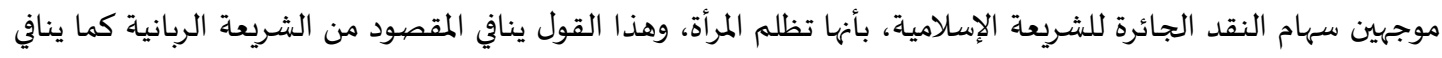

عدل الله سبحانه وتعالى بين عباده" (77).

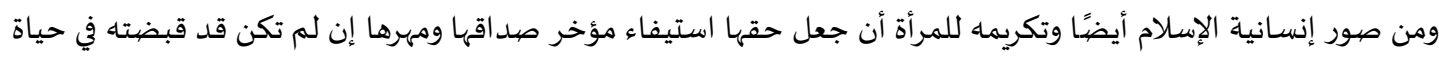

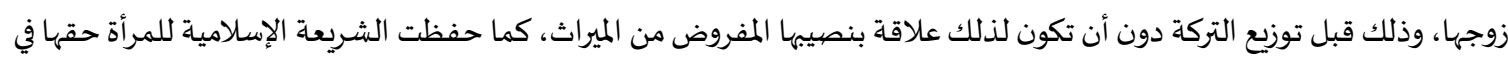

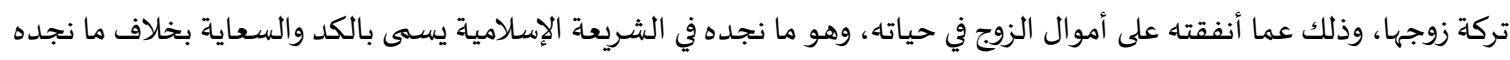

اليوم في بعض القوانين المعاصرة والتي تعطي الأخ كل التركة (78) فئان.

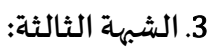

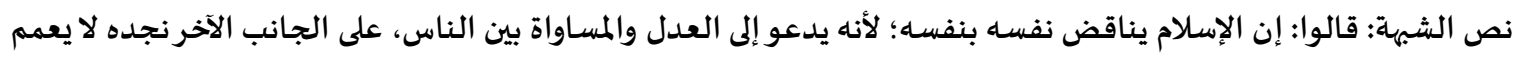

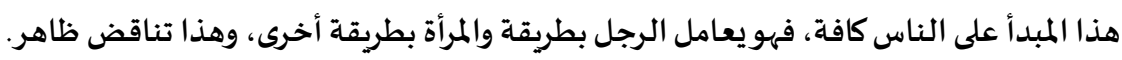

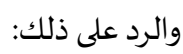

$$
\text { أن الميراث للمرأة في الإسلام هو تأكيد حقها الإنساني. }
$$

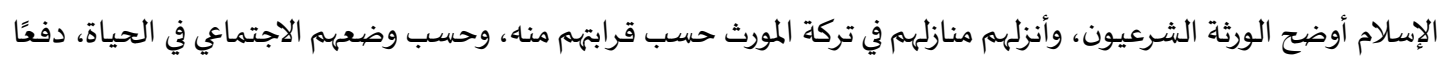
للتهم التي أخذت الإسلام عند مفكرو الغرب.

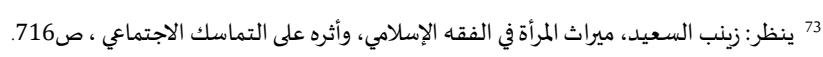

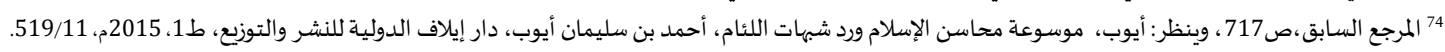

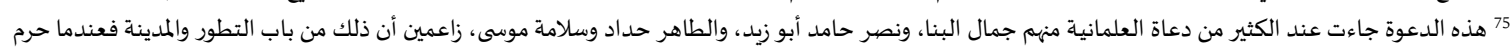

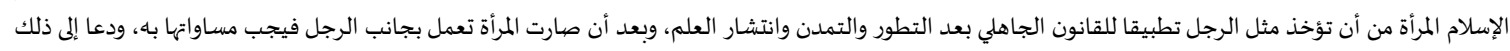

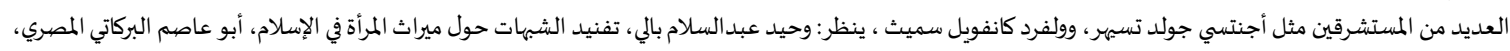

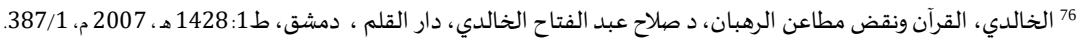

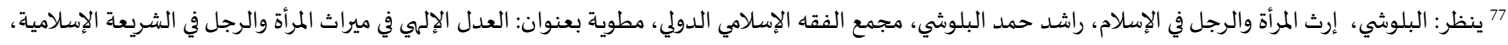

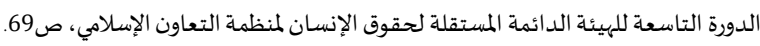

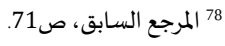




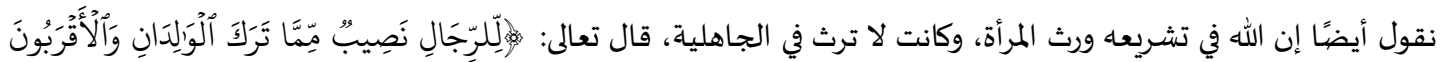

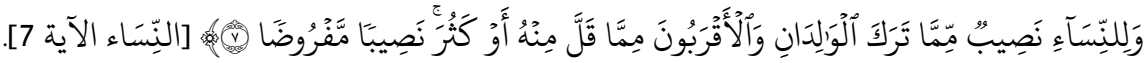

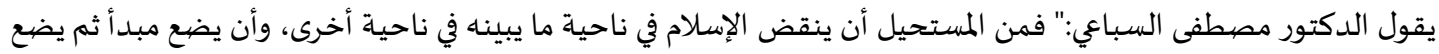

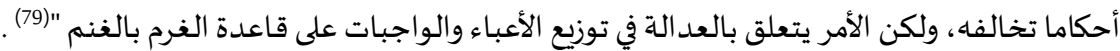

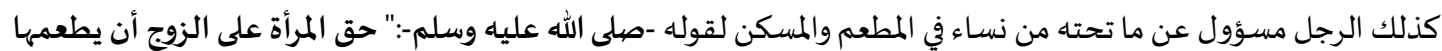

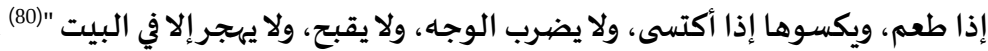

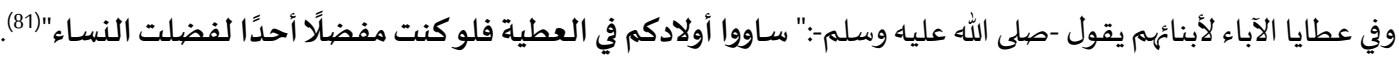

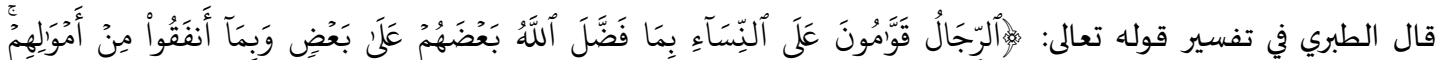

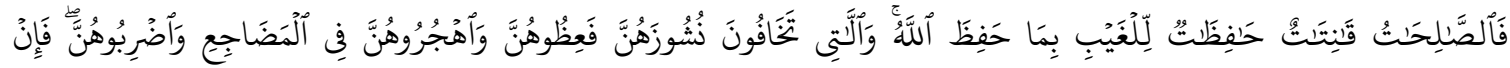

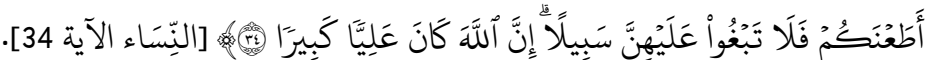

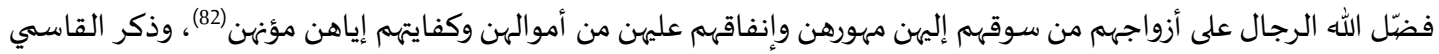

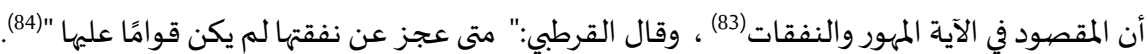

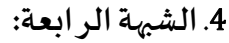

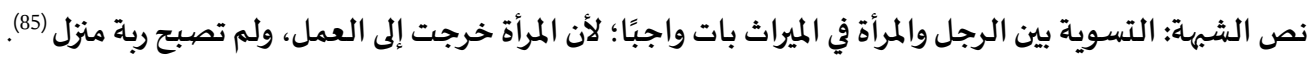

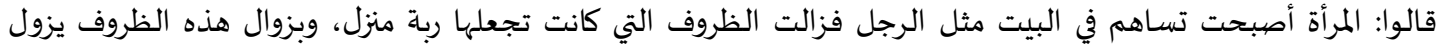

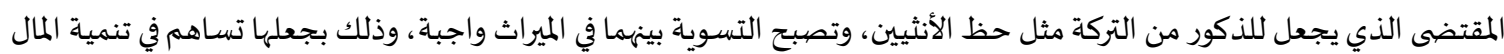
مثلها مثل زوجها.

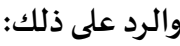

خروج المرأة للعمل في الإسلام له ضوابط وشروط معينة، وينظر إلى ما ينطوي عليه ذلك من مشاكل جمة على الأسرة، والزوج، والأولاد. • أن الله تعالى بين مقادير الإرث في القرآن الكريم فذكر النصف والربع والثلثين والثلث والسدس، ونحو ذلك، ولم يذكر عدد

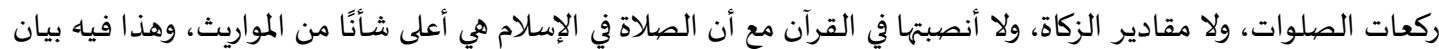

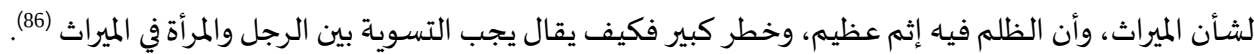

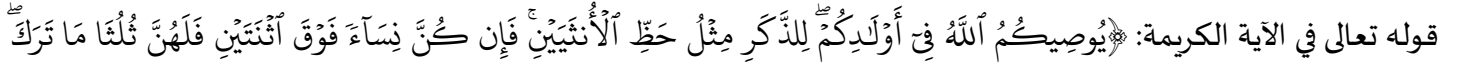

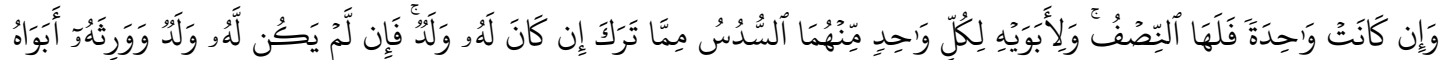

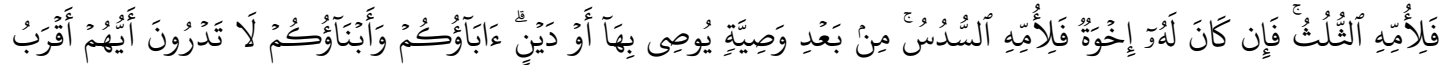

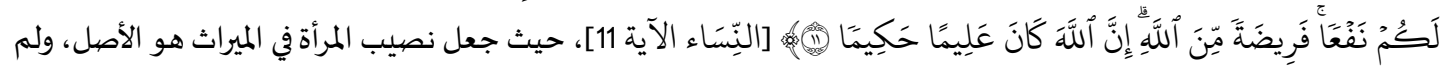

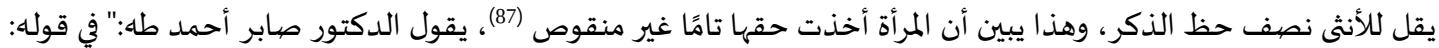

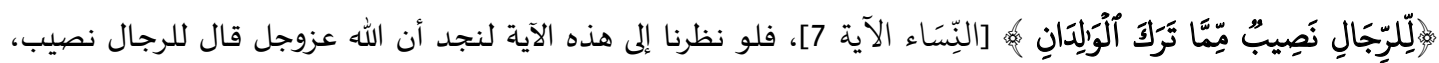

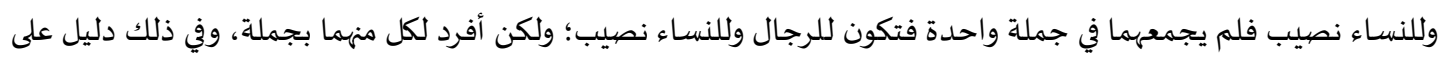

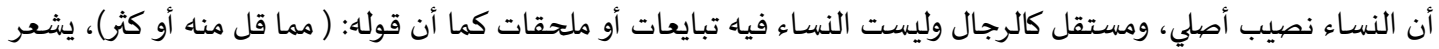

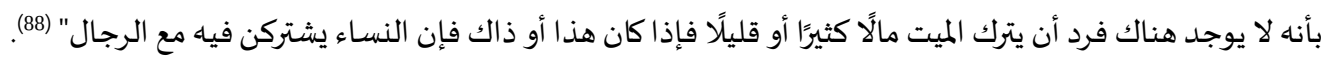

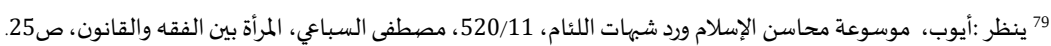

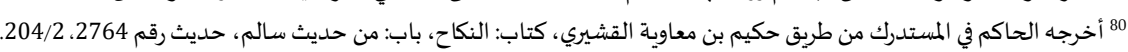

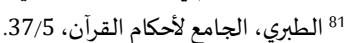

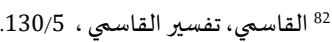
83 المرجع السابق، $831 / 5$ الماسي، تفير الفاسي 1739/3 الطبري، الجامع لأحكام القرآن،

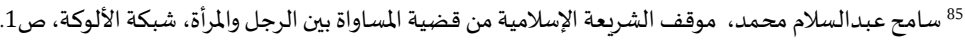

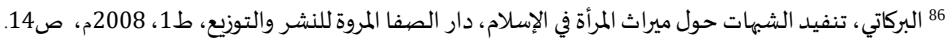

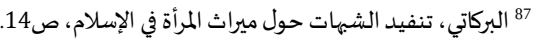
88 ينظر : أيوب، موسوعة محاسن الإسلام ورد شبهات اللئام، 548/11. 
أولاً: مقولات الغربيين المنصفة لنظام الميراث في الإسلام:

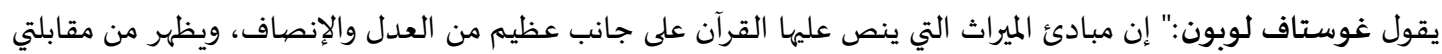

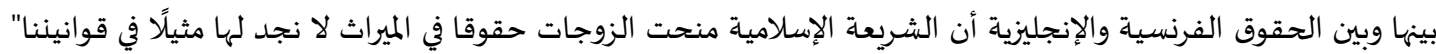

هقول (ماسينيون):" يعلن أن الإسلام لديه من الكفاية ما يجعله يتشدد في تحقيق فكرة المساواة، وذلك بفضل زكاة يدفهها كل

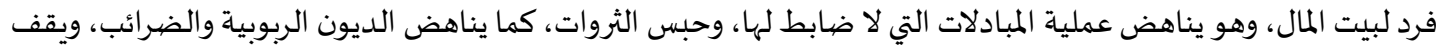

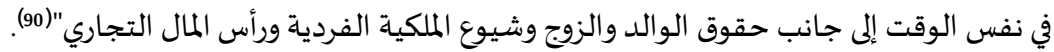

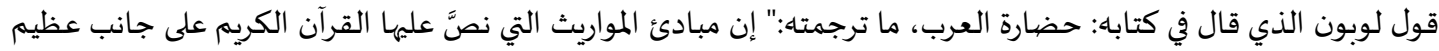

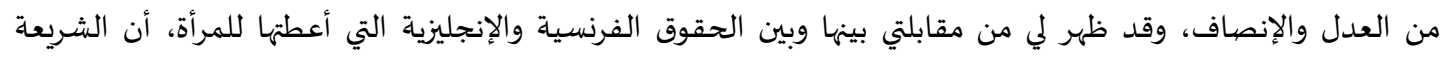

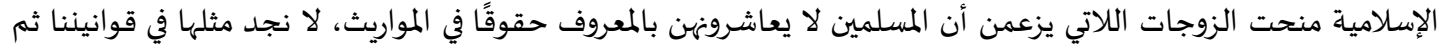

أضاف قائلا: إن الدين الإسلامي هو الدين الأوحد الذي الذي أعطى للمرأة حقًًا في الميراث (91).

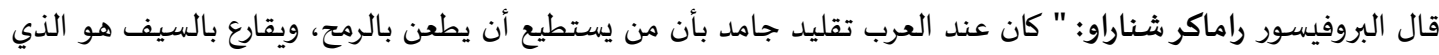

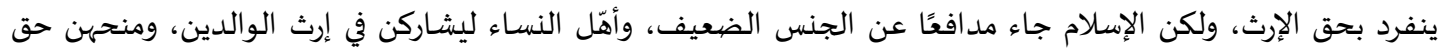

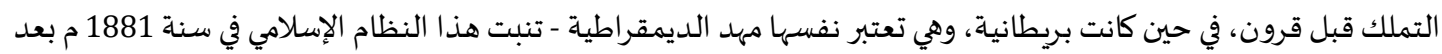

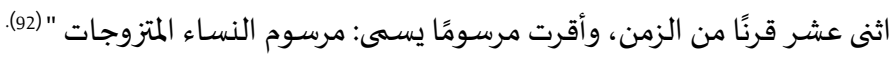

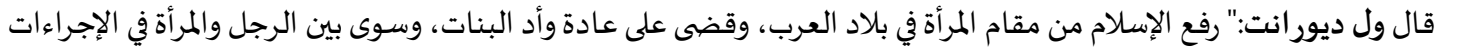

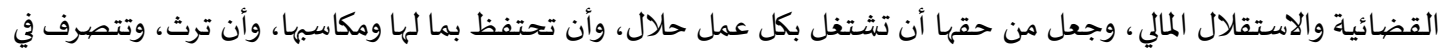

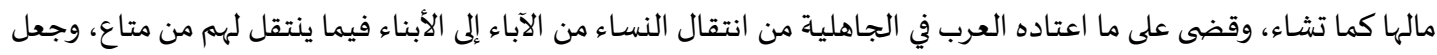

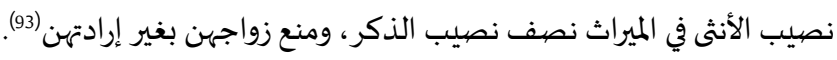

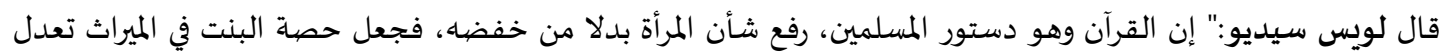

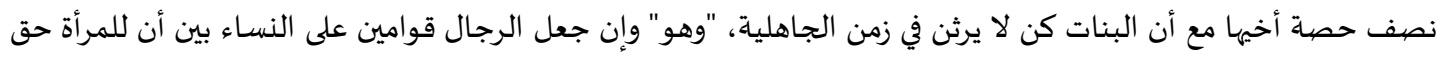

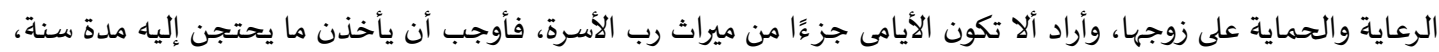

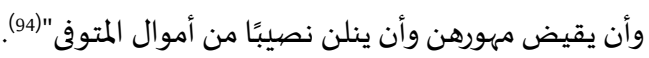

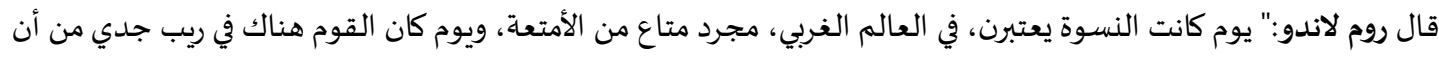

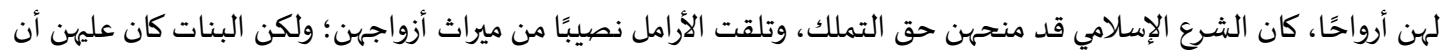

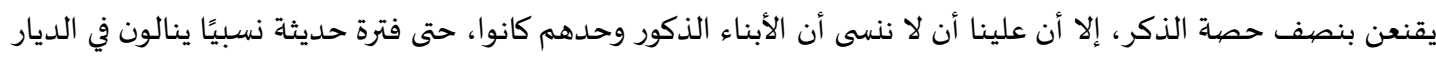
الغربية حصة من الإرث" (95).

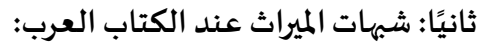
• ن إنجيب محفوظ

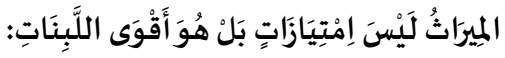

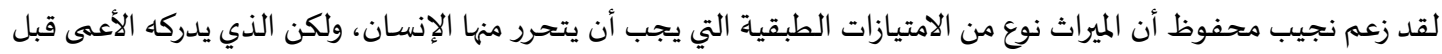

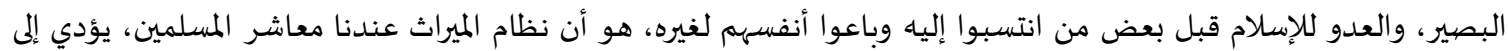

89 غوستاف، حضارة العرب، غوستاف لوبون، ترجمة: عادل زعيتر، ط1، 2012م، ص32.

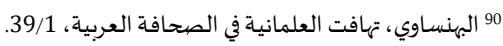

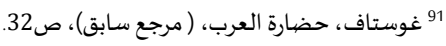

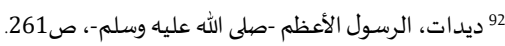

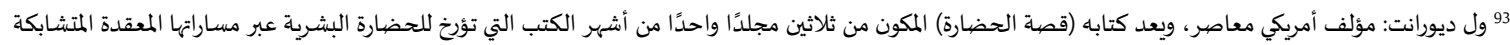

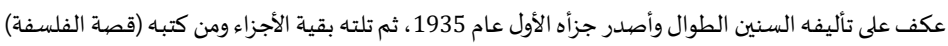

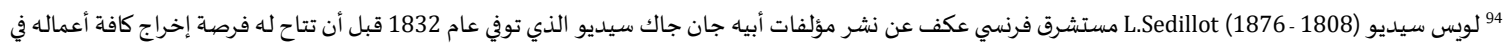

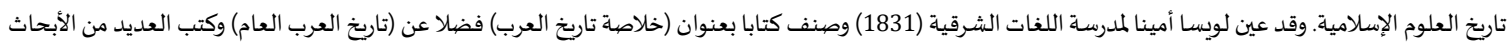
والدراسات في المجلات المعروفة.

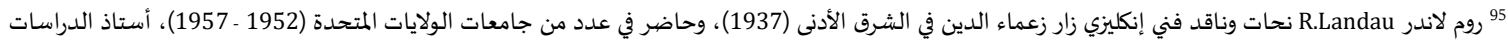

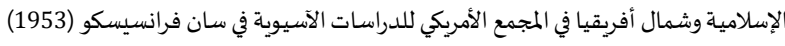


تفتيت الثروة وتذويب الطبقات، كما يؤدي إلى الترابط بين الآباء والأبناء، فضلًا عن أنه يخلق في الفرد الباعث على الإنتاج، كما يربط

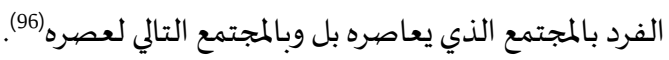

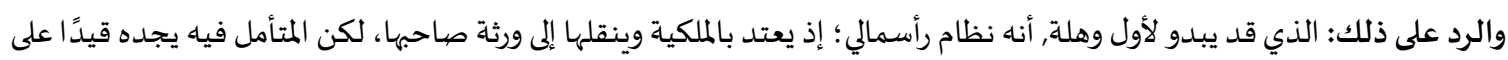
الملكية؛؛ إذ يجري توزيعها وفق نظام دقيق يكفل:

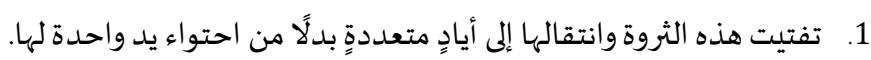

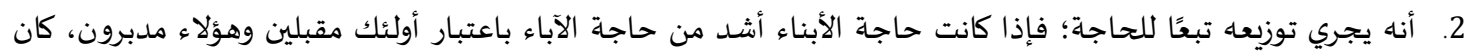

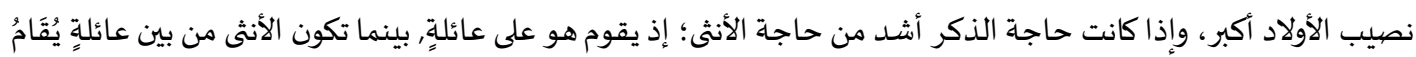
عليها، كان كذلك نصيب الذكر أكبر (97).

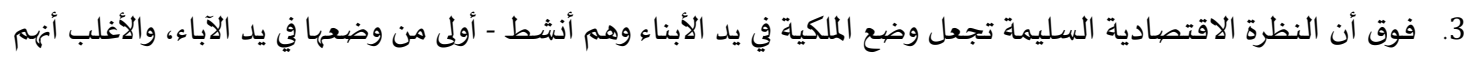

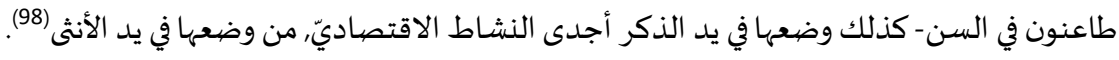

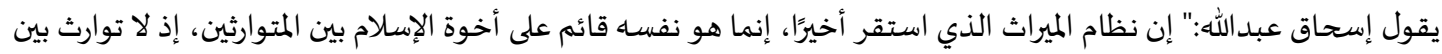

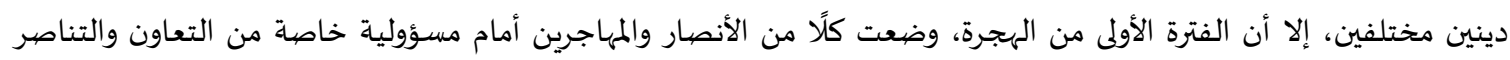

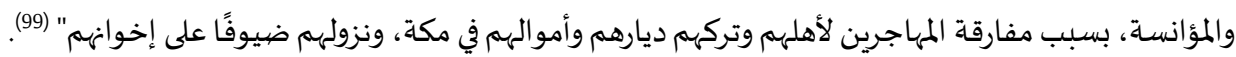

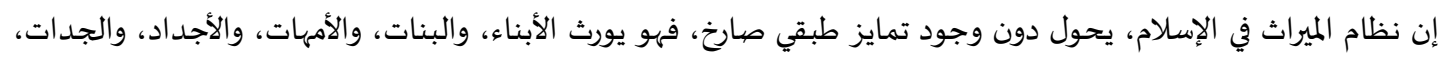

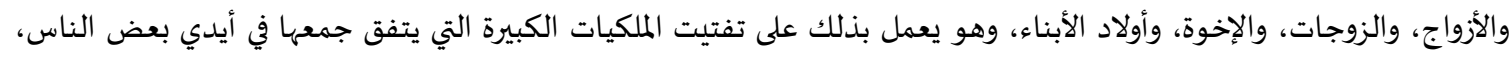

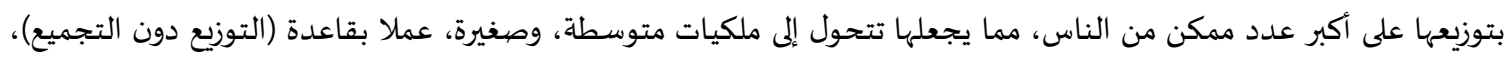
وذلك للمحافظة على التوازن الاقتصادي في المجتمع.

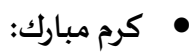
نظام الميراث الإسلامي ظلم المرأة كثيرًا، ومن حقنا كنساء أن نطالب بتغييره تونس غيرت نظام الميراث ومصر لازم تغير نظامها؛

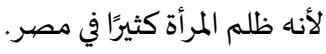

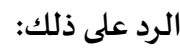

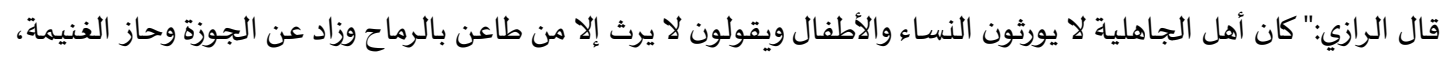

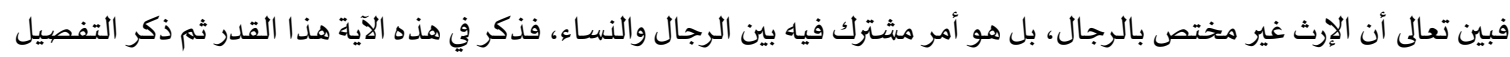
بعد ذلك (100).

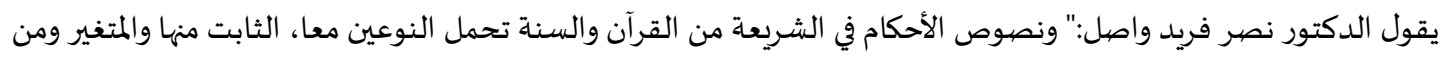

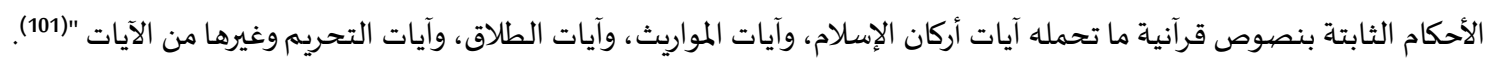

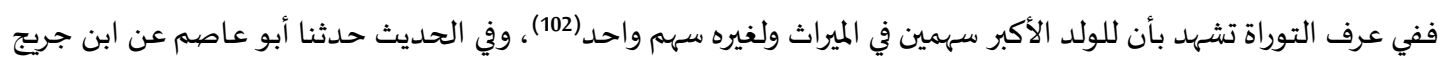

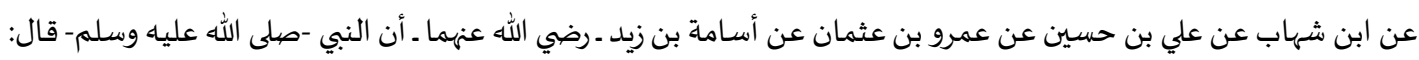

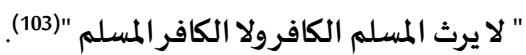

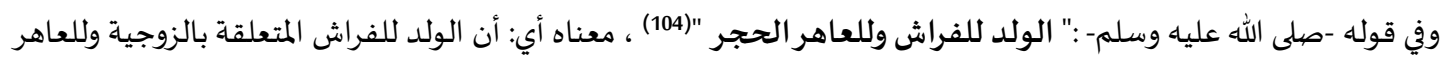

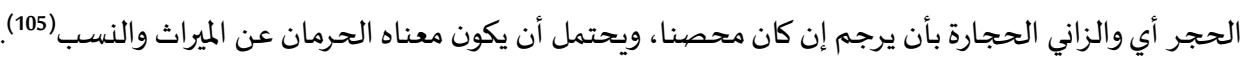

96 ينظر: الهينساوي، تهافت العلمانية في الصحافة العربية، المستشار سالم علي الهينساوي(ت 1427ه)، دار الوفاء للطباعة والنشر والتوزيع، المنصورة، مصر، ط1، 1990م، 97 ينظر: الزبيق، وعلي جريشه، أساليب الغزو الفكري للعالم الإسلامي، على محمد جريشه، و محمد شريف الزببق، دار الوفاء، الفئ، ط3، 1979، 233/1.

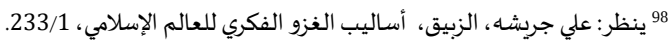

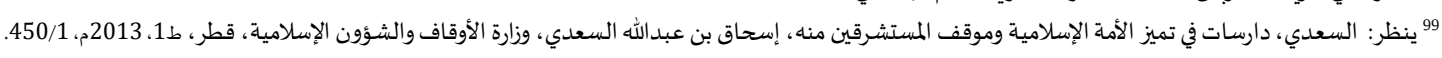
201 100

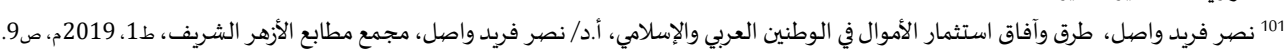

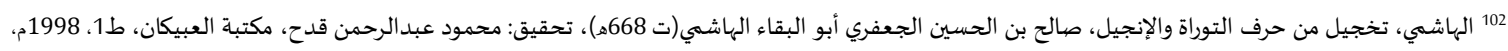

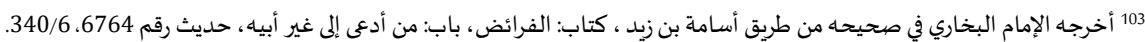

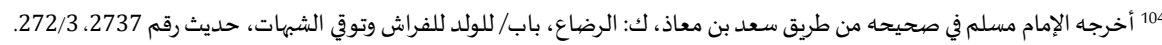

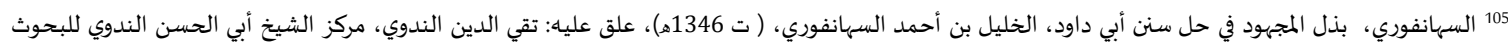

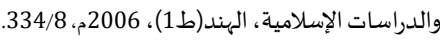


وقال ابن عاشور:" كانوا قد اعتادوا إيثار الأقوياء والأشداء بالأموال وحرمان الضعفاء وأخص الناس بذلك النساء فإنهن يجدن إنهاء

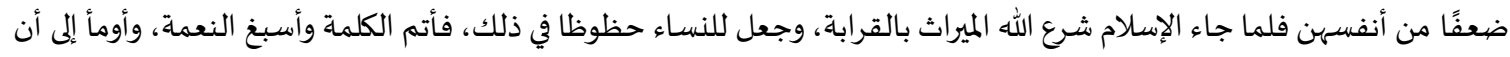

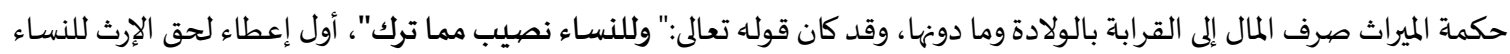
في العرب" (106). إن هناك من المؤلفين والمفكرين الغربيين من أنصف نظام الميراث في الإسلام، ووصفاه بأن فيه من العدل والإنصاف للمرأة ما لا

$$
\text { يوجد مثله في القوانين الغربية. }
$$

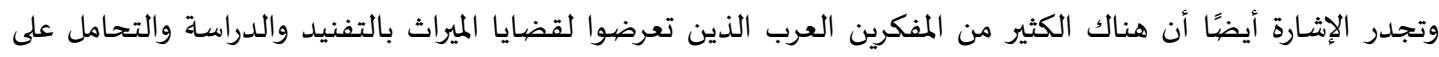

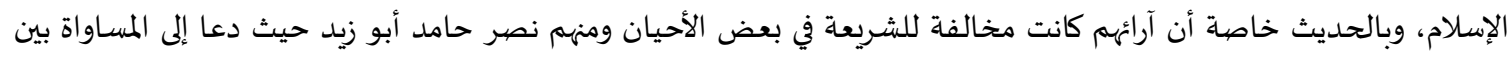

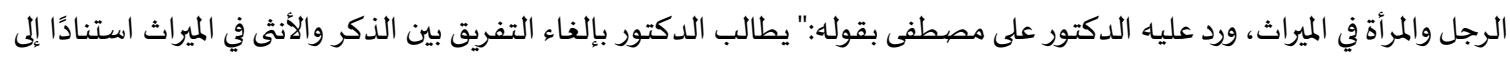

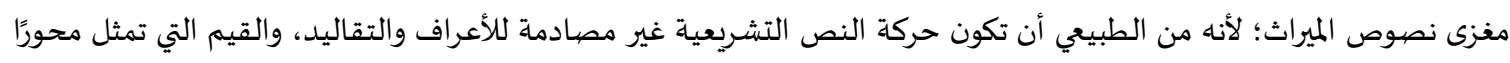

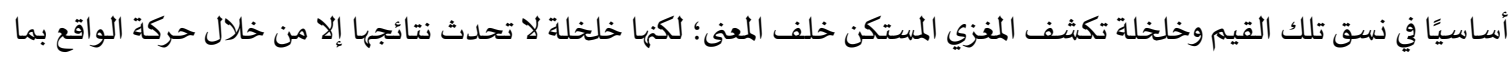

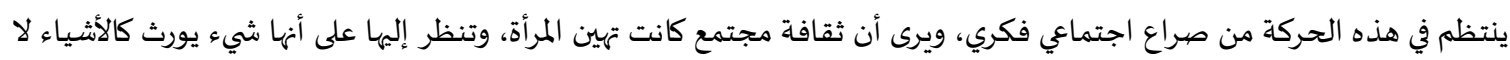

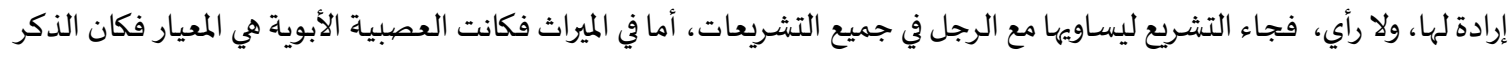

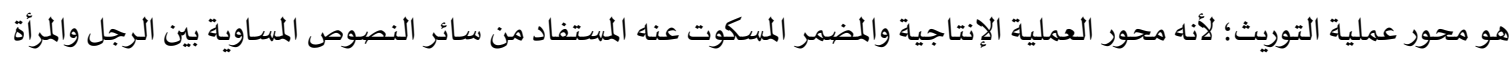
هو مغزى النص الذي يلغي حرفيته بالتطور الثقافي والاجتماعي (107).

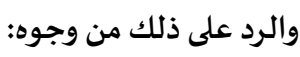

الوجه الأول: أن الإسلام صندم بتشريعاته الأصهول والفروع كرفض الشرك والتعصب القبلي، وإهانة الأنثى وحرمة الربا.

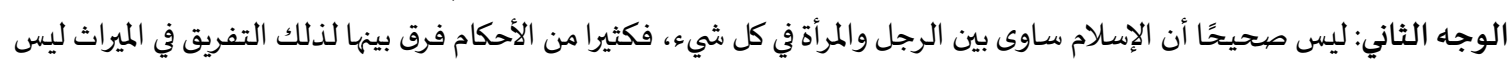
تشريعا شاذًا. الوجه الثالث: نظام الميراث في الإسلام ينبثق عن نظرته للمرأة التي صاغها في في عشرات النصيوص والأحكام، فهي ليست مصدرًا

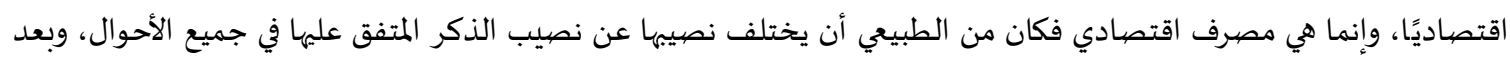

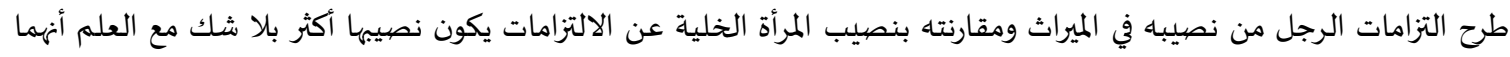
يتساويان في بعض الحالات الأخرى لحكم آخر (108).

الخاتمة: أولاًا: النتائج: أمقصود بالإعجاز التشربعي في الميراث هو: إثبات عجز البشر جميعًا عن الإتيان بمثل ما ورد في الشريعة الإسلامية من تشريعات وأحكام تتعلق بتقسيم التركة للميت.

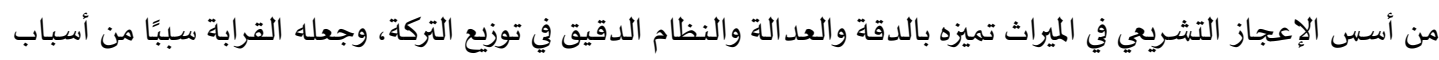

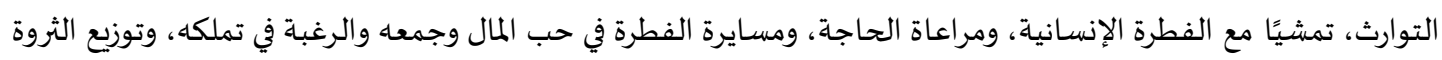
وتفتتيت الملكيات لنشرها وعدم تكدسها في أياد قليلة.

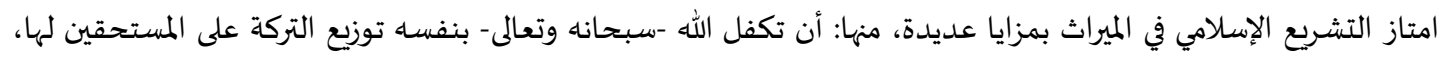

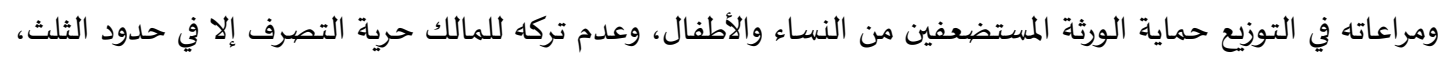

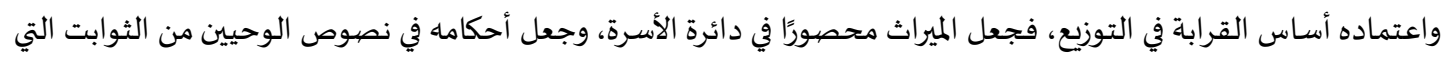

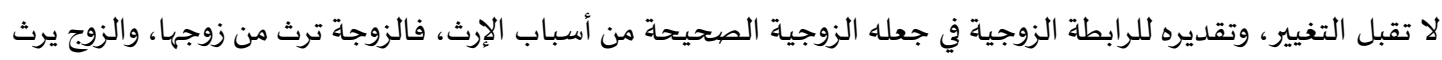
من زوجتاه.

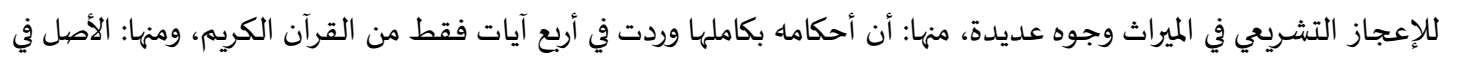

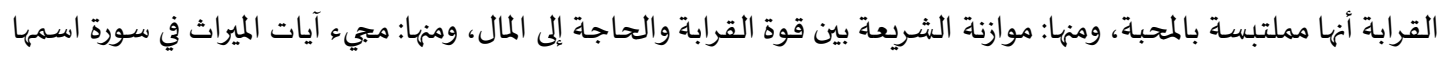


سورة النساء، وهذا يشعر بالثورة التي يقيمها القرآن على المجتمع الجاهلي وضرورة التخلص من عاداته وإعطاء المرأة مكانتها،

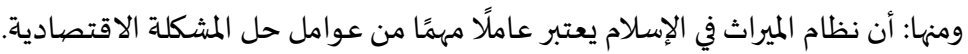

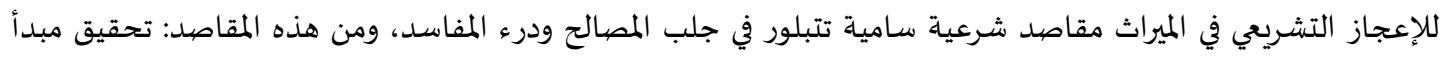

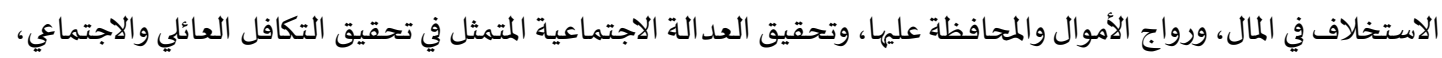

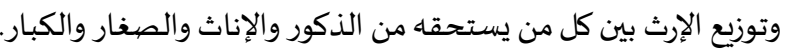

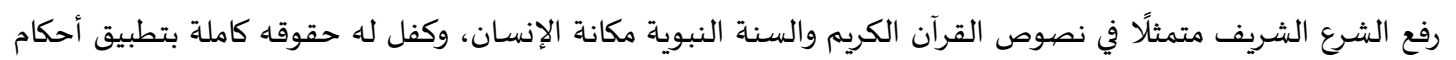

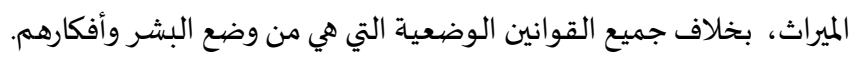

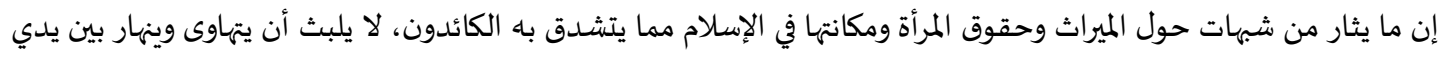

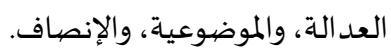

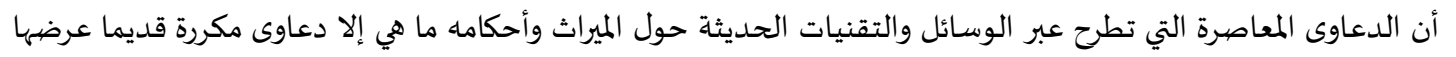

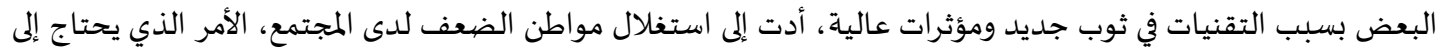

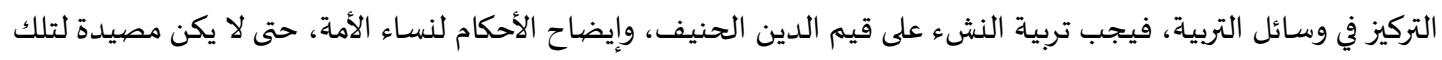

الدعاوى وأصحابها.

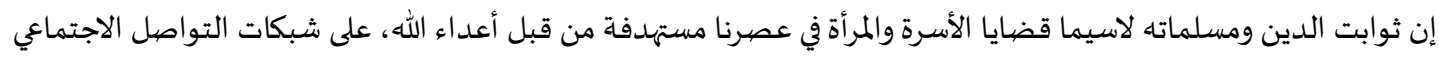

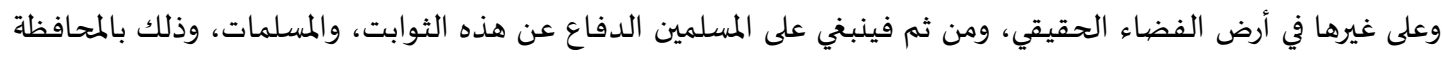

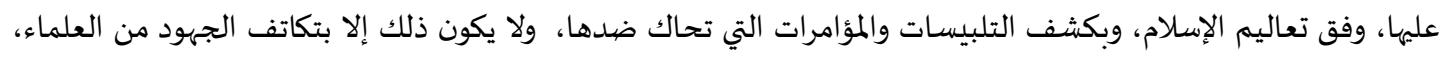

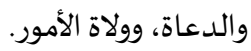
ثانيًا: التوصيات:

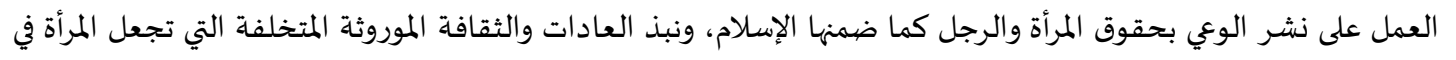

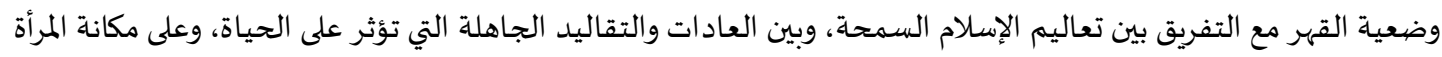

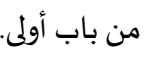
بذل الجهود الكبيرة والحثيثة؛ لإبراز حقيقة الإسلام، وكيفية تعامله مع أحكام الميراث، واستغلال وسائل التقنية الحديثة في

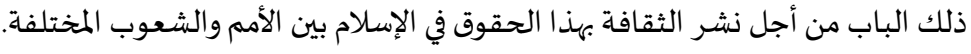

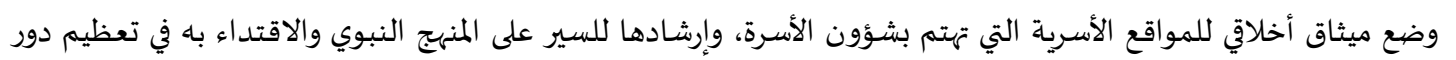

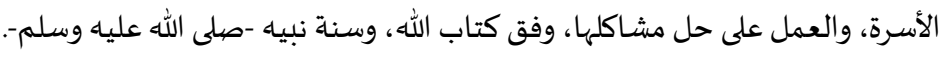

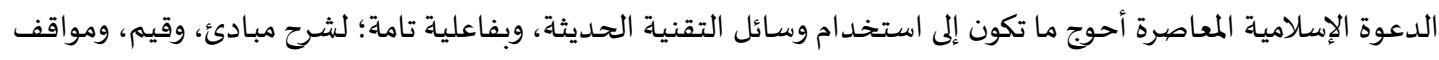

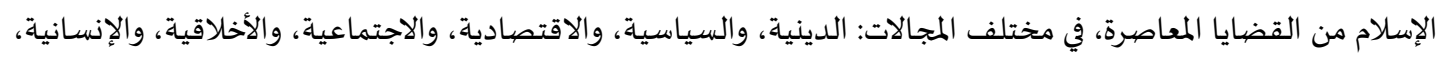

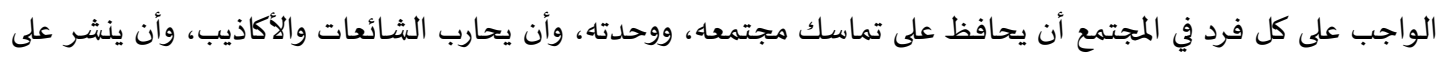

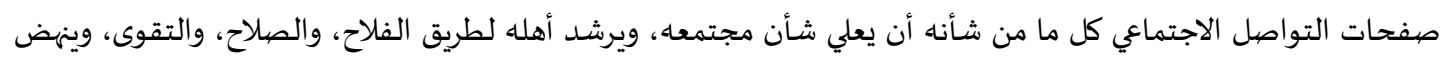

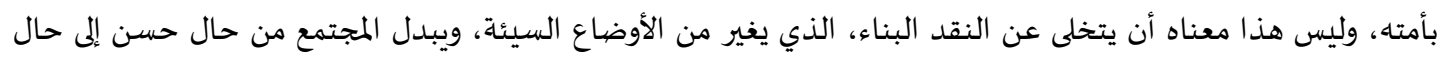
أحسن على طريق التنمية والبناء.

1. إبراهيم، أسماء صابر عبدالعليم (2018). الأسرة ودورها في عملية التنشئة الاجتماعية للطفل وانعكاسات ذلك على التفاعل

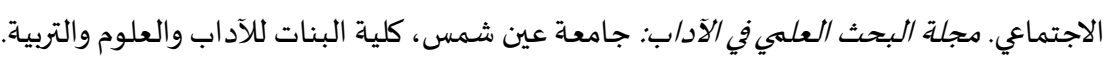

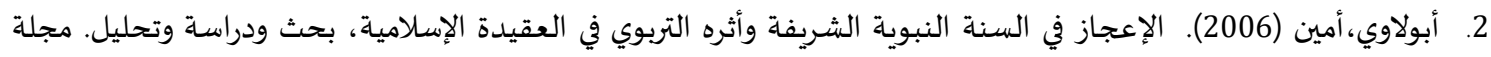
جامعة عين شمس: (112).

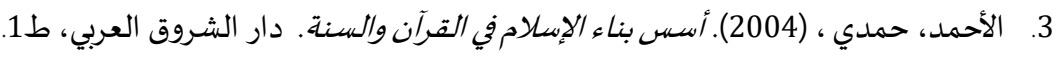

4.

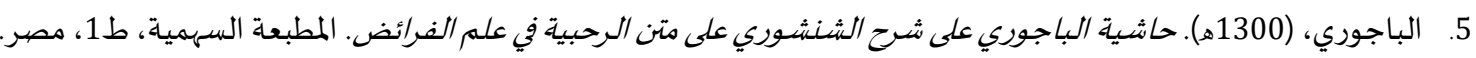


6. باوزير، مريم (2011). أهلية المرأة وأثرها في الحقوق والواجبات. مجلة مركز البحوث والدراسات الإسلامية: جامعة القاهرة، كلية دار العلوم، مركز البحوث والدراسات الإسلاصية ، 7 (24).

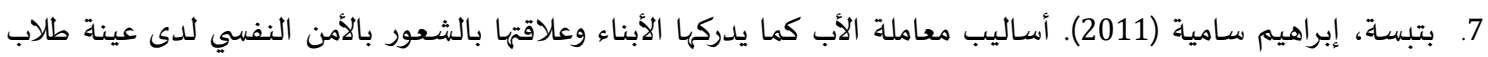

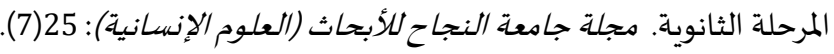
8. البخاري (1422هـ). الجامع المسند الصحيح المختصر من أمور رسول الله -صلى الله عليه وسلم- وسننها وأيامهاه [ صحيح البخاري].

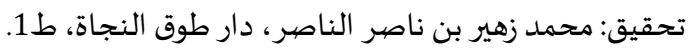
9. البخاري (1989). الأدب المفرد. محمد بن إسماعيل بن إبراهيم بن المفيرة البخاري، أبو عبد الله (ت 256هـ)، المحقق: محمد فؤاد

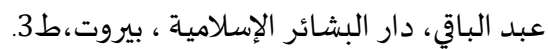

10. بركات، سليم (2016). الثقافة مفهوم وممارساة. اتحاد الكتاب العبرب: 45 (539).

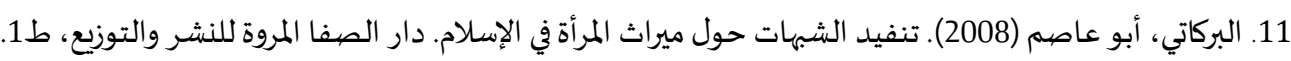
12. بطراني، عبد العزيز (2005). أساليب التنشئة الاجتماعية في ظل المنهج الإسلامي. الرابطة المحمدية للعلماء.

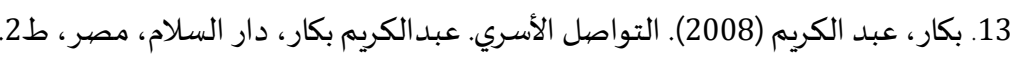
14. بلكيلاني، إبراهيم (2008). تقدير الذات وعلاقته بقلق المستقبل لدى الجالية العربية المقيمة بملدينة أوسلو في النرويج. رسالة ماجستير في علم النفس غير منشورة، الأكاديمية العربية المفتوحة في الدنمارك. 15. البلعاوي، سيف الدين (2009). الإعجاز التشريعي للقرآن في كل من نظام الميراث، نظام الطاقلاق. بحث منشور في أعمال المؤتمر

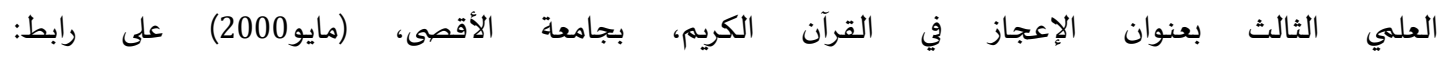
https://search.mandumah.com/Record/507440 16. البلوشي (2014). إرث الممأة والرجل في الإسلام. راشـد حمد البلوشي، مجمع الفقه الإسلامي الدولي، مطوية بعنوان: العدل الإلهي

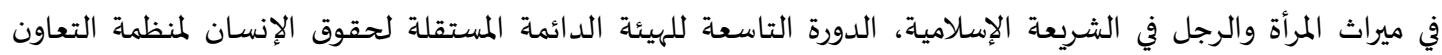
الإسالامي.

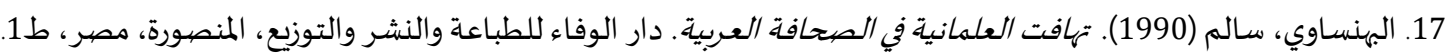

18. توفيق، فتحية محمد (1981). الأسرة والزواج في الإسلام. مجلة الوعي الإسلامي: وزارة الأوقاف والشؤون الإسلامية، (205).

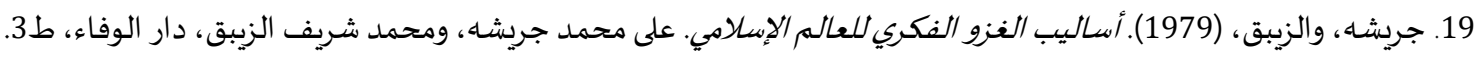

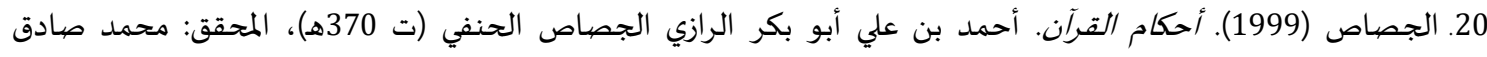

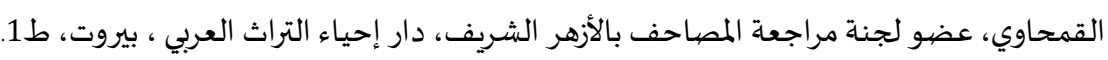

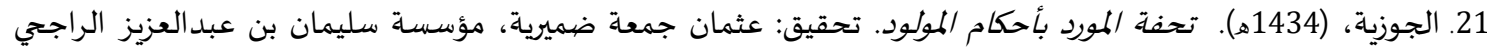

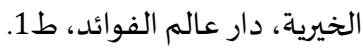

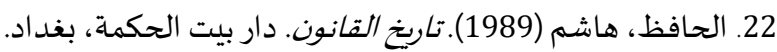

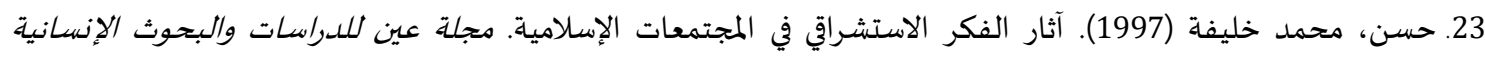
والاجتماعية، ، القاهرة. 24. دجان، دون (1994). الأسرة والعلاقات الحميماة، مسارات الحياة الأسرية، وإعادة بناء الحياة الخاصة. المجلة الدولية للعلوم الاجتماعية: منظمة اليونسكو، (139) دون (139).

25. أبو الدهب، أحمد (1996). الأسرة والتنشئة الاجتماعية للطفل. مجلة الوعي الإسلامي. وزارة الأوقاف والشؤون الإسلامية، 26. الديبسي، محمد (2012). حق بناء الأسرة للإنسان في الإسلام. مجلة هلدى الإسلام: وزارة الأوقاف والشئون والمقلدات الإسبامية ، 56 (6) 27. الرقيب، أحمد (2009). آيات الميراث في القرآن الكريم .. دراساة بيانية. جامعة العلوم التطبيقية، منشور في" المجلة الأردنية في الدراسات الإسبامية" : 5 (3/ب).

28. الرهاوي، يحيى (1439ه). حاشية الرهاوي. ( مطبوع علي شرح المنار )(مخطوط)، مركز البحث العلمي، بجامعة أم القرى، ط1.

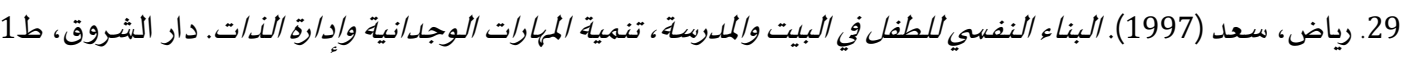
30. الزبيدي، مرتضى (2002). تاج العروس من جواهر القاموس. تحقيق: مجموعة من المحققين، دار الهداية، ط6. 31. السحيم، محمد عبدالله (1421ه). الإسالام أصوله ومبادؤه. وزارة الشؤون الإسلامية والأوقاف والدعوة والإرشاد، المملكة مجنة 
32. السعدي، عبد الرحمن (2001).تيسير الكريم الرحمن في تفسير كلام المنان. جمعية إحياء التراث الإسلامي، الكويت ، ط1.

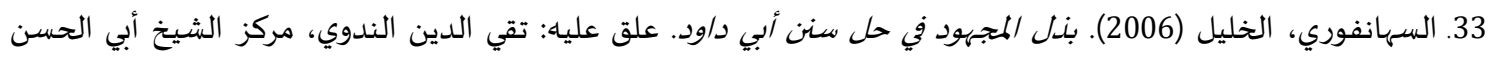

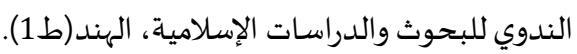

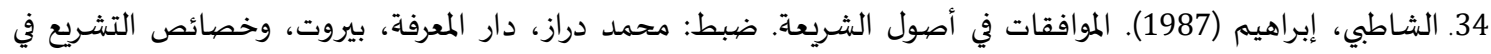

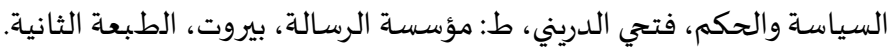

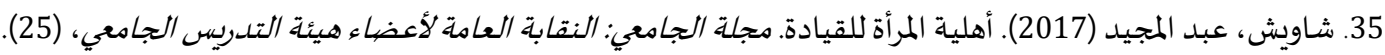

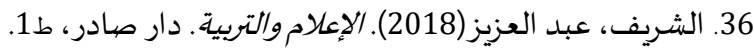

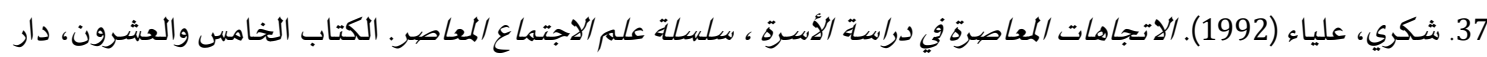

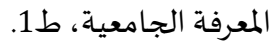

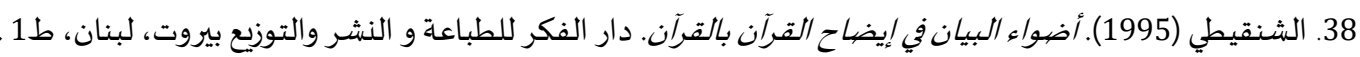

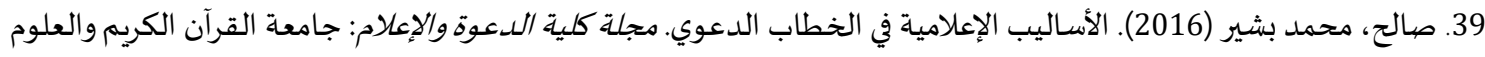

الإسلامية، كلية الدعوة والإعلام، العدد(3).

40. الصاوي، أحمد (1998). حد الكفاية في قضايا النفقة. المستشار محمد أكديد، نقلا عن التسولي على التحفة، الجزء الأول، الألادية

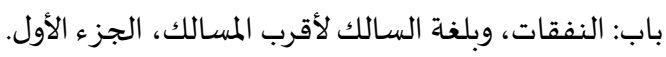

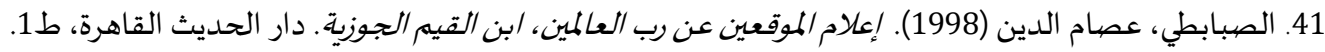

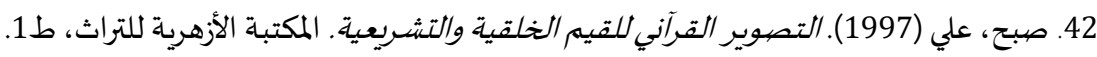

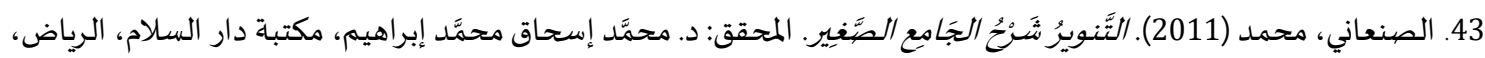

طـ 1432،

44. ضياء الدين (2011). الأساس التعبدي للتربية الإسلامية. بنان أحمد ضياء الدين، رسالة ماجستير، جامعة إلرموك، كلية الشريعة والدراسات الإسلامية، الأردن.

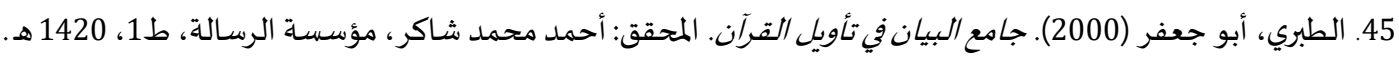

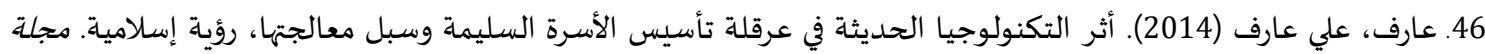

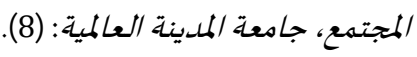
47. ابن عاشور، (1984)، التحريروالتنوير تحرير المعنى السلديد وتنوير العقل الجديد من تفسير الكتاب المجيد]. الدار التونسية

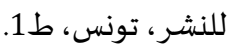
48. عبد الحميد، شيرين (2001). الإعجاز التشريعي في الحقوق الاقتصادية المشتركة بين الرجل والموأة كدليل على تكريم المرأة. بحوث المؤتمر العالمي العاشر للإعجاز العلمي في القرآن والسنة.

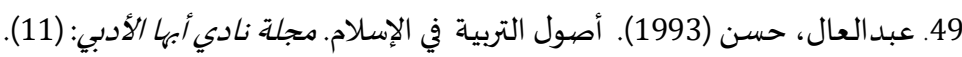

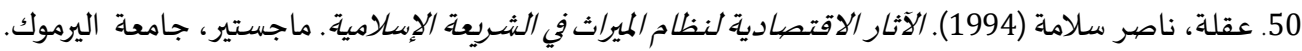

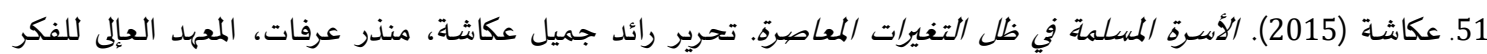
الإسلامي، ط1. 52. علوان، عبد الله (1981). تربية الأولاد في الإسلام. دار السلام، بيروت، ط3.

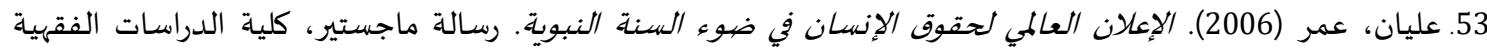

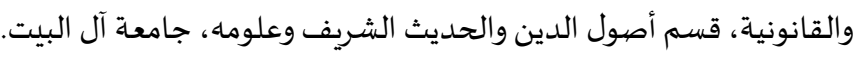

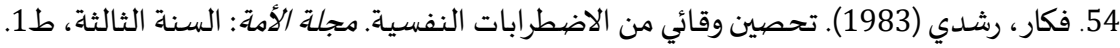

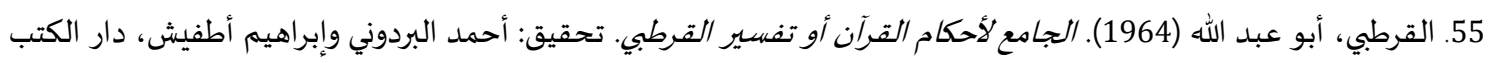

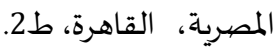

56. القرني، صافية (2008). الإسهامات التربوية للحوار في بناء شخصية المسلم وتطبيقاتها في الأسرة والمدرسة. رسالة ماجستير، جامعة أم القرى، كلية التربية.

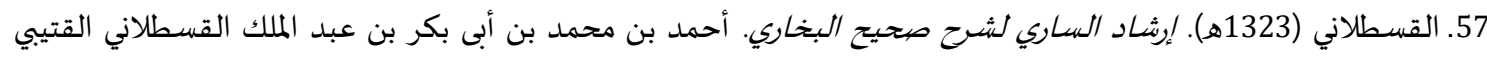

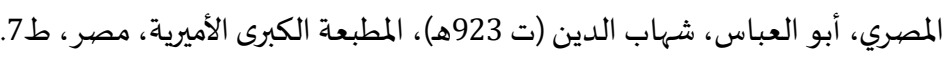

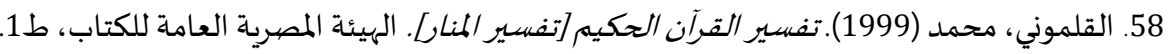




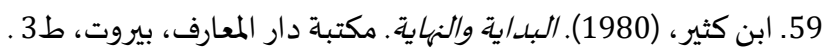

60. ابن كثير، (1419ه). تفسير القرآن العظيم. تحقيق: محمد حسين شمس الدين، دار الكتب العلمية، منشورات محمد علي

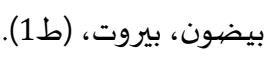

61. متولي، محمد محمود (1989). اختيار الأم الصبالحة. مجلة الوعي الإسلامي: وزارة الأوقاف والشئون الإسلامية، أكتوبر.

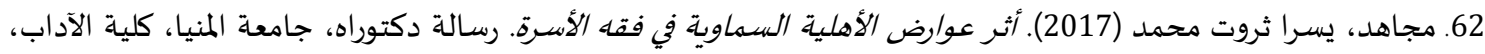

$$
\text { قسم الدراسـات الإسلامية. }
$$

63. بن محمد، علي (1998). التعريفات. الطبعة الأولى، دار الكتب العلمية، بيروت.

64. مختار، مجي الدين (1998). التنشئة الاجتماعية المفهوم والأهداف. مجلة العلوم الإنسانية، قسنطينة: منشورات جامعة الأسة

قسنطينة ، (9).

65. المرزوقي، عمر (2001). اقتصياديات الميراث في الإسلام. مجلة مركز صالحكامل للاقتصياد الإسلامي: جامعة الأزهر، 5 (14). 66. المصري، غيداء (2005). أهلية المرأة في الشريعة الإسلامية، دراسة مقارنة. رسالة دكتوراه، جامعة دمشق، كلية الشريعة، سوريا.

67. مفزع، جمعان حسن (2015). أسس بناء الأسرة في القرآن الكسيه والسنة النبوية وانعكاساتها على تنشئة الطفل. رسالة ماجستير، جامعة الإمام محمد بن سعود الإسلامية.

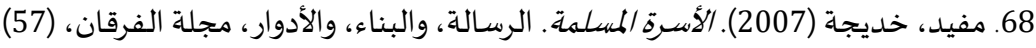

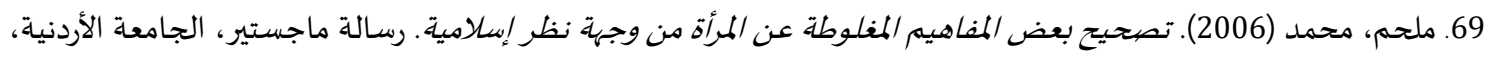
كلية الدراسات العليا. 70. النمري، ناريمان (2014). الاليات الدولية والشرعية الخاصة بحماية حقوق المرأة في ظل العولمة. ماجستير، كلية الحقوق، جامعة الشـارقة.

71. نور الدين، محمد (2001). التنشئة الاجتماعية للطفل. مجلة سيكولوجية التوبية: (3). 72. النيسابوري (2004). الإجماع، محمدل بن إبراهيم بن المنندر النيسابوري. تحقيق ودراسـة: د. فؤاد عبد المنعمم أحمد، دار المسلم

$$
\text { للنشر والتوزيع، ط1. }
$$

73. الهاشمي، صالح (1998). تخجيل من حرف التوراة والإنجيل. تحقيق: محمود عبدالرحمن قدح، مكتبة العبيكان، ط1. 74. وصفي، عبدالعزيز (2019). الاجتهاد الفقهي المالكي ودوره في رعاية حقوق الأسرة واستيعاب نوازلها، إمهال الزوجة للتجهيزيز

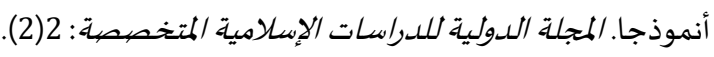

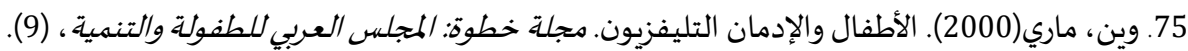




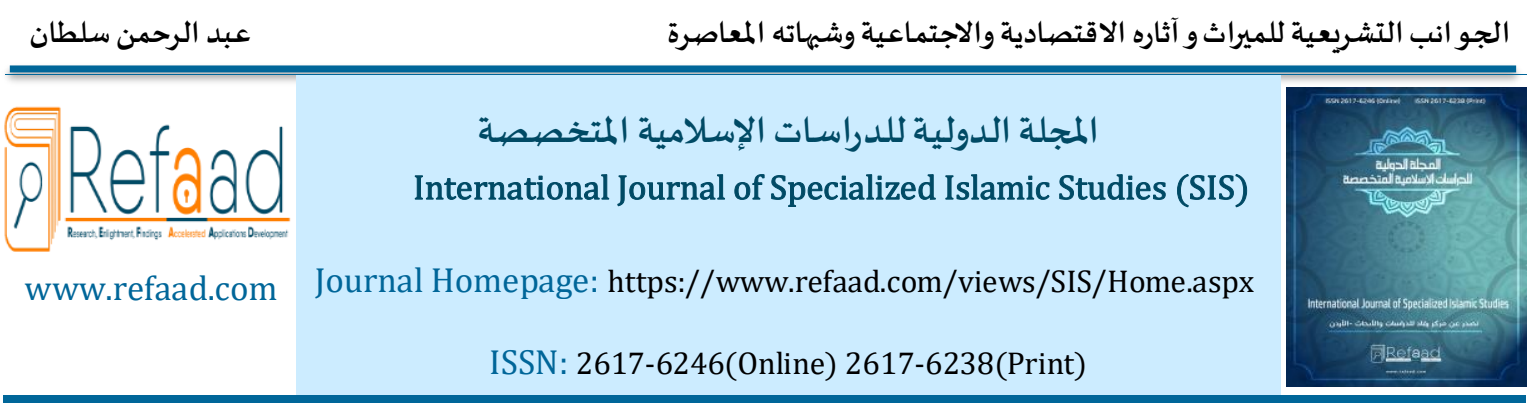

\title{
Legislative aspects of inheritance and its economic and social effects and contemporary suspicions- A study in the texts of the two revelations
}

\author{
Abdel Rahman Abdel Nasser Sayed Sultan \\ Assistant Professor of Hadith and its Sciences, Faculty of Arts, Minia University, Egypt \\ dr.abdalrhman2014@yahoo.com
}

Received: 26/9/2021 Revised: 30/9/2021 Accepted: 16/10/2021 DOI: https://doi.org/10.31559/SIS2021.6.2.3

Abstract: The research is limited to a set of basic frameworks that clarify its features, namely: the inheritance system in Islam, its foundations and goals, and its social and economic effects through studying the verses of the Holy Qur'an and the purified biography of the Prophet Muhammad Peace be upon him. The study dealt with the concept of inheritance, its pillars, conditions, causes and impediments, the legislative aspects of women's inheritance, the socio-economic impact of the inheritance system in Islam and contemporary suspicions about the Islamic legal system in inheritance and responses to them. It is commensurate with the legal provisions and the preservation of rights for them by knowing the sound controls set by the Islamic Sharia in dealing with heirs. Among the most important findings it has reached is that the legislative miracle of inheritance has lofty legitimate aims that crystallize in bringing interests and warding off evil. Some of these objectives are achieving the principle of succession in money, the popularity and preservation of money, achieving social justice represented in achieving family and social solidarity, and distributing inheritance among all who deserves it, whether being a male or a female, young or old.

Keywords: legislation; women; inheritance; impact.

\section{References:}

1. Alahmd, Hmdy, (2004). Ass Bna' Aleslam Fy Alqran Walsnh. Dar Alshrwq Al'rby, T1.

2. Alanw't, 'bd Alqadr (1403h). Thfh Almwlwd Bahkam Almwlwd. Alryad, Dar 'alm Alktb, T1.

3. Albajwry, (1300h). Hashyh Albajwry 'la Shrh Alshnshwry 'la Mtn Alrhbyh Fy 'Im Alfra'd. Almtb'h Alshmyh, T1, Msr.

4. Bawzyr, Mrym (2011). Ahlyh Almrah Wathrha Fy Alhqwq Walwajbat. Mjlt Mrkz Albhwth Waldrasat Aleslamyh: Jam't Alqahrh, Klyt Dar Al'lwm, Mrkz Albhwth Waldrasat Aleslamyh,7 (24).

5. Albhnsawy, Salm (1990). Thaft Al'lmanyh Fy Alshafh Al'rbyh. Dar Alwfa' Lltba'h Walnshr Waltwzy', Almnswrh, Msr, T1.

6. Albkhary (1422h). Aljam' Almsnd Alshyh Almkhtsr Mn Amwr Rswl Allh -Sla Allh 'lyh Wslm- Wsnnh Wayamh[ Shyh Albkhary]. Thqyq: Mhmd Zhyr Bn Nasr Alnasr, Dar Twq Alnjah, T1.

7. Albkhary (1989). Aladb Almfrd. Mhmd Bn Esma'yl Bn Ebrahym Bn Almghyrh Albkhary, Abw 'bd Allh (T 256h), Almhqq: Mhmd F'ad 'bd Albaqy, Dar Albsha'r Aleslamyh, Byrwt,T3.

8. Bkar, 'bd Alkrym (2008). Altwasl Alasry. 'bdalkrym Bkar, Dar Alslam, Msr, T2.

9. Blkylany, Ebrahym (2008). Tqdyr Aldat W'laqth Bqlq Almstqbl Lda Aljalyh Al'rbyh Almqymh Bmdynh Awslw Fy Alnrwyj. Rsalt Majstyr Fy 'Im Alnfs Ghyr Mnshwrh, Alakadymyh Al'rbyh Almftwhh Fy Aldnmark.

10. Albl'awy, Syf Aldyn (2009). Ale'jaz Altshry'y Llqran Fy Kl Mn Nzam Almyrath, Nzam Altlaq. Bhth Mnshwr Fy A'mal Alm'tmr Al'lmy Althalth B'nwan Ale'jaz Fy Alqran Alkrym, Bjam't Alaqsa, (Mayw2000) 'la Rabt: https://search.mandumah.com/record/507440 
11. Alblwshy (2014). Erth Almrah Walrjl Fy Aleslam. Rashd Hmd Alblwshy, Mjm' Alfqh Aleslamy Aldwly, Mtwyh B'nwan: Al'dl Alelhy Fy Myrath Almrah Walrjl Fy Alshry'h Aleslamyh, Aldwrh Altas'h Llhy'h Alda'mh Almstqlh Lhqwq Alensan Lmnzmh Alt'awn Aleslamy.

12. Brkat, Slym (2016). Althqafh Mfhwm Wmmarsh. Athad Alktab Al'rb: 45 (539).

13. Btbsh, Ebrahym Samyh (2011). Asalyb M'amlt Alab Kma Ydrkha Alabna' W'laqtha Balsh'wr Balamn Alnfsy Lda 'ynh Tlab Almrhlh Althanwyh. Mjlt Jam't Alnjah Llabhath (Al'lwm Alensanyh): 25(7).

14. Btrany, 'bdal'zyz (2005). Asalyb Altnsh'h Alajtma'yh Fy Zl Almnhj Aleslamy. Alrabth Almhmdyh Ll'Ima'.

15. Ebrahym, Asma' Sabr 'bdal'lym (2018). Alasrh Wdwrha Fy 'mlyh Altnsh'h Alajtma'yh Lltfl Wan'kasat Dlk 'la Altfa'l Alajtma'y. Mjlt Albhth Al'Imy Fy Aladab: Jam't 'yn Shms, Klyt Albnat Lladab Wal'lwm Waltrbyh.

16. Abwlawy,Amyn (2006). Ale'jaz Fy Alsnh Alnbwyh Alshryfh Wathrh Altrbwy Fy Al'qydh Aleslamyh, Bhth Wdrash Wthlyl. Mjlt Jam't 'yn Shms: (112).

17. Albrkaty, Abw 'asm (2008). Tnfyd Alshbhat Hwl Myrath Almrah Fy Aleslam. Dar Alsfa Almrwh Llnshr Waltwzy', T1.

18. Abw Aldhb, Ahmd (1996). Alasrh Waltnsh'h Alajtma'yh Lltfl. Mjlt Alw'y Aleslamy. Wzarh Alawqaf Walsh'wn Aleslamyh, (363).

19. Djan, Dwn (1994). Alasrh Wal'laqat Alhmymh, Msarat Alhyah Alasryh, We'adh Bna' Alhyah Alkhash. Almjlh Aldwlyh Ll'lwm Alajtma'yh: Mnzmh Alywnskw, (139).

20. Aldybsy, Mhmd (2012). Hq Bna' Alasrh Llensan Fy Aleslam. Mjlt Hda Aleslam: Wzarh Alawqaf Walsh'wn Walmqdsat Aleslamyh, 56(6).

21. Alhafz, Hashm (1989). Tarykh Alqanwn. Dar Byt Alhkmh, Bghdad.

22. Hsn, Mhmd Khlyfh (1997). Athar Alfkr Alastshraqy Fy Almjtm'at Aleslamyh. Mjlt 'yn Lldrasat Walbhwth Alensanyh Walajtma'yh, Alqahrh.

23. Jryshh, Walzybq, (1979). Asalyb Alghzw Alfkry Ll'ealm Aleslamy. 'la Mhmd Jryshh, Wmhmd Shryf Alzybq, Dar Alwfa', T3.

24. Aljsas (1999). Ahkam Alqran. Ahmd Bn 'ly Abw Bkr Alrazy Aljsas Alhnfy (T 370h), Almhqq: Mhmd Sadq Alqmhawy, 'dw Ljnh Mraj't Almsahf Balazhr Alshryf, Dar Ehya' Altrath Al'rby , Byrwt, T1.

25. Aljwzyh, (1434h). Thfh Almwrd Bahkam Almwlwd. Thqyq: 'thman Jm't Dmyryh, M'sst Slyman Bn 'bdal'zyz Alrajhy Alkhyryh, Dar 'alm Alfwa'd, T1.

26. Alrhawy, Yhya (1439h). Hashyh Alrhawy. (Mtbw' 'ly Shrh Almnar)(Mkhtwt), Mrkz Albhth Al'lmy, Bjam't Am Alqra, T1.

27. Alrqyb, Ahmd (2009). Ayat Almyrath Fy Alqran Alkrym.. Drash Byanyh. Jam't Al'lwm Alttbyqyh, Mnshwr Fy "Almjlh Alardnyh Fy Aldrasat Aleslamyh": 5 (3/B).

28. Ryad, S'd (1997). Albna' Alnfsy Lltfl Fy Albyt Walmdrsh, Tnmyh Almharat Alwjdanyh Wedarh Aldat. Dar Alshrwq, T1.

29. Twfyq, Fthyh Mhmd (1981). Alasrh Walzwaj Fy Aleslam. Mjlt Alw'y Aleslamy: Wzart Alawqaf Walsh'wn Aleslamyh, (205).

30. Alzbydy, Mrtda (2002). Taj Al'rws Mn Jwahr Alqamws. Thqyq: Mjmw't Mn Almhqqyn, Dar Alhdayh, T6. 